DEPARTMENT OF ECONOMICS

\title{
A Small Open Economy New Keynesian DSGE model for a foreign exchange constrained economy
}

Sisay Regassa Senbeta

\author{
UNI VERSI TY OF ANTWERP \\ Faculty of Applied Economics \\ Stadscampus \\ Prinsstraat 13, B.226 \\ BE-2000 Antwerpen \\ Tel. +32 (0)32654032 \\ Fax +32 (0)3 2654799

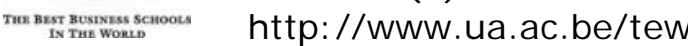




\title{
FACULTY OF APPLIED ECONOMI CS
}

\author{
DEPARTMENT OF ECONOMICS
}

\section{A Small Open Economy New Keynesian DSGE model for a foreign exchange constrained economy}

Sisay Regassa Senbeta

RESEARCH PAPER 2011-004

MAY 2011
University of Antwerp, City Campus, Prinsstraat 13, B-2000 Antwerp, Belgium Research Administration - room B.226 phone: (32) 32654032 fax: (32) 32654799
e-mail: joeri.nys@ua.ac.be

The papers can be also found at our website: www.ua.ac.be/tew (research $>$ working papers) $\&$ www.repec.org $/$ (Research papers in economics - REPEC)

D/ 2011/ 1169/004 


\title{
A Small Open Economy New Keynesian DSGE model for a foreign exchange constrained economy*
}

\author{
Sisay Regassa Senbeta ${ }^{\dagger}$ \\ Department of Economics, University of Antwerp
}

May 4, 2011

\begin{abstract}
Firms in many low income countries depend entirely on imported capital and intermediate inputs. As a result, in these countries economic activity is considerably influenced by the capacity of the economy to import these inputs which, in turn, depends on the availability and cost of foreign exchange. In this study we introduce foreign exchange availability as an additional constraint faced by firms into an otherwise standard small open economy New Keynesian DSGE model. The model is then calibrated for a typical Sub Saharan African economy and the behaviour of the model in response to both domestic and external shocks is compared with the standard model. The impulse response functions of the two models are the same qualitatively for most of the variables though the model with foreign exchange constraint generates more variability in most of the variables than the standard model. This behaviour of the model with foreign exchange constraint is consistent with the stylized facts of low income countries. Furthermore, for variables for which the two models have different impulse response functions, the model with foreing exchange constraint is both theoretically consistent and matches the stylized facts.
\end{abstract}

JEL classification: E32, F31, F41, O55

Keywords: New Keynesian DSGE, Foreign exchange constraint, Low income countries, SubSaharan Africa

${ }^{*}$ I would like to thank professor Guido Erreygers for constructive comments and suggestions as well as for pointing out many flaws at various stages of the paper. I am greatful to professor Wim Meeusen who provided me with many critical comments. I am also indebted to professor Jordi Gali for the invaluable hint he provided me on how to approach the problem discussed in this paper. This paper was presented at the Lunchtime Seminar of the Department of Economics, University of Antwerp, on March 21, 2011. I would like to thank seminar participants for useful comments and suggestions. The responsibility for all remaining errors is mine.

${ }^{\dagger}$ Stadscampus S.B. 135, Prinsstraat 13, 2000 Antwerp, Belgium. SisayRegassa.Senbeta@ua.ac.be 


\section{Introduction}

The recent financial crisis and commodity price fluctuations invigorate the argument that the availability and cost of foreign exchange play a crucial role in the macroeconomic performance of low income countries. The reason is that firms in low income countries such as those in most of Sub-Saharan African countries (hereafter SSA) operate in an environment where almost all physical capital and intermediate inputs are imported. As a result, the availability and cost of foreign exchange to import these inputs play a critical role in the production process. In this study we attempt to formally assess this claim by introducing a foreign exchange constraint faced by firms into an otherwise standard small open economy New Keynesian dynamic stochastic general equilibrium (DSGE) model. To our knowledge, there is only one study, (Kose and Reizman, 2001), that applied a simple open economy DSGE model of the real business cycle tradition to assess the impact of external shocks (both financial and trade shocks) on macroeconomic performance of African countries. In their study, Kose and Reizman recognize the importance of imported intermediate inputs in determining production in these countries, but their analysis falls short of accounting for the role of the availability of foreign exchange in determining import of intermediate inputs and thereby production.

In most standard macroeconomic models intermediate inputs and physical capital are either produced domestically or the economy faces no constraint in importing these inputs. In a similar way, the New Keynesian DSGE models that have become the workhorse to analyze the behaviour of the macroeconomy in the short-run make the same assumption. Consequently, these models, in their standard form, are of little use to investigate how macroeconomic variables respond to various domestic and external shocks in economies where firms face foreign exchange constraint to import intermediate inputs and physical capital ${ }^{1}$.

There are different studies, though not within the context of the DSGE framework, that show the crucial role that the availability and cost of foreign exchange play in the macroeconomic performance of developing and low income countries (Agenor and Monteil, 2008; Lensink, 1995; Moran, 1989; Polterovich and Popov, 2003; Porter and Ranney, 1982; Stiglitz et al 2006). Porter and Ranney (1982:753) argue that in a typical low income country, in the short run, expanding output without

\footnotetext{
${ }^{1}$ It is worth noting that there is ample literature that recognizes the constraints that households face to convert their savings into capital, or the constraints that firms face in the production process (like shortage of working capital). But this literature is mainly about credit constraints and credit market frictions and does not model foreign exchange explicitly. As we will argue in this paper modeling foreign exchange will also capture the credit constraint that firms face.
} 
increasing cost of production could be possible "provided only that foreing exchange can be located to purchase the needed raw material imports". This argument is based on the characteristic features of the low income economies that they and many other authors share. One of these charactristic features is that shortage of foreign exchange forces firms to produce below their capacity. They also illustrate the policy implications of this characteristic feature of low income economy in a simple but very instructive IS-LM framework. Agenor and Monteil (2008) and Stiglitz et al (2006) also assert that the availability of foreign exchange is crucial supply determining factor in developing countries. For instance, Stiglitz et al (2006:56) argue that

... the problem for many developing countries is the deficiency of productive capacity and not the anomaly of its underutilization. And, ..., the availability of foreign exchange may become, under many circumstances, the principal factor limiting economic activity. Demand constraints do exist, ... , but supply constraints - generated either by the availability of capital or by the availability of foreign exchange - are more important.(Emphasis added)

We argue that dependence of production on imported intermediate inputs and, therefore, on availability of foreign exchange is one of those circumstances to which Stiglitz and his co-authors refer.

The empirical literature on this issue, though few, also supports this argument. For instance, Moran (1989) studied the effect of the fall in inflow of foreign exchange in the early 1980s, due to declined foreign lending, rise in interest rates on debts, and fall in commodity prices, on volume and composition of imports of developing countries. His result shows that most of the countries considered were affected negatively. Sub Saharan African countries, according to Moran (1989), experienced significant fall in imports which, in turn, led to deterioration of investment and a fall or stagnant per capita output. Linsink (1995) also assessed the effect of the same phenomenon (fall in the foreign exchange inflows into low income countries in 1980s). But unlike Moran (1989), Linsink (1995) investigates the effect on overall macroeconomic performance with an emphasis on economic growth. His simulation analysis shows that SSA countries are among the hard-hit. He deduced that, other things being the same, improvement of economic growth in low income countries depends on availability of foreign exchange to import intermediate inputs. The results of these two studies (Moran, 1989 and Linsink, 1995) imply that the imports of low income countries are mainly intermediate inputs and capital. This concurs with the study by Kose and Reizman (2001) that shows that over the period 1970-1990 the proportion of intermediate inputs and capital in the total imports was more than 75 percent (approximately 48 
and 28 percent, respectively) for African countries. Under such circumstances, it is not surprising that decreasing import results into decreasing investment and output. Likewise, Polterovich and Popov (2003) in their empirical study of the relationship between the accumulation of foreign exchange reserve, on the one hand, and investment and growth, on the other, using cross-country regression find strong positive links. That is, developing countries with growing stocks of foreign exchange tend to show higher growth of investment to GDP ratios and higher GDP growth rates. We expect this to be true for the economies of SSA given the economic structure of the countries in the region.

Hence, we argue that for low income countries like those in SSA, foreign exchange needs to be considered as a crucial input that constrains production, employment and other macroeconomic variables since imported capital and intermediate inputs are all dependent primarily on the availability of foreign exchange and therefore also on its price, the exchange rate.

The claim that the change in foreign exchange reserve of the country can have significant consequences on the evolution of macroeconomic variables and hence needs closer examination when modeling low income economies, can be defended on various grounds. First, some production sectors in these countries depend heavily on imported inputs - raw materials, intermediate inputs, and capital. Hence, the availability of foreign exchange to import these inputs influences the level of production. For example, the recent global financial crisis that entailed a fall in inflows of foreign exchange into low income countries from export revenues, remittances and other sources, led to foreign exchange rationing. This, in turn, resulted into significantly reduced production or complete suspension of production by imported-input intensive firms in some countries. Second, modeling only the imported intermediate inputs, as in Kose and Reizman (2001), cannot capture some of the effects of the inflows of foreign exchange on domestic production. There are studies that show that increasing availability of foreign exchange in developing countries enhances the confidence of foreign investors (see, for instance, Polterovich and Popov (2003)). The argument is that an increasing availability of foreign exchange in a country improves the ability of the country to allow foreign investors to repatriate their profits. This implies that the availability of foreign exchange has also an external effect since it attracts more firms in addition to serving as an input for already existing firms. In other words, just like the relative resource abundance attracts investors, at least in this part of the world, the availability of foreign exchange also does. Third, the availability of foreign exchange can serve as a composite input that captures the effects of external resources (aid, loan, and remittance) on the performance of the economy. Fourth, according to Wyplosz (2007), some countries see accumulation of foreign exchange reserve as an insurance against financial shocks which has significant implications on macroeconomic 
performance. This is so since accumulation of foreign exchange enhances the confidence of both domestic and foreign economic agents. For domestic producers and consumers it implies that the country can afford to continue imports while for foreign agents dealing with the economy it gives signal that the country can always meet its obligations, even in the event of temporary shocks to inflow of foreign exchange. Finally, modeling foreign exchange availability and its cost will capture the effect of credit constraints faced by firms in developing countries. Literature shows that one of the constraints of firms in developing countries is the lack of credit as initial capital (for investment - import of capital) or as working capital to import intermediate inputs ${ }^{2}$. Introduction of foreign exchange constraint to firms can also capture the effect of credit constraint as the largest proportion of the credit demand by firms is for capital and intermediate inputs which are dependent indirectly on the availability of foreign exchange and its cost.

As a stylized fact, the inflow of foreign exchange into these countries shows significant variability due to the erratic nature of export earnings, aid, loans and remittances. Further more, studies show that some components of the inflow of foreign exchange from some of these sources coincides with the performance of the domestic economy, with the shortage coming when the economy needs it most (see Bulir and Hamann, 2008 and 2003). Thus, incorporating the foreign exchange constraint when modeling the macrodynamics of low income countries seems superior to exclusively relying on imported intermediate goods to capture the fluctuation of economic activity due to global financial and trade shocks. This, we believe, will also enrich the dynamics of the model. Furthermore, we assume that the availability of foreign exchange is more important for firms that are producing non-tradable goods than for those producing tradable goods. In the context of low income countries, this assumption is reasonable since in times of shortage priority is given to firms that produce tradable goods on the expectation that they generate more foreign exchange through export and/or substitute imports thereby save foreign exchange and, therefore, ease the scarcity.

This study, being the first work to incorporate the availability of foreign exchange in to the DSGE framework, contributes towards understanding how low income economies respond to global financial and trade shocks. The model in this paper can be used to investigate the impact of various shocks such as access to international debt market, aid volatility, commodity price fluctuations and shocks

\footnotetext{
${ }^{2}$ Fafchamps (2004) in an extensive study of market institutions in Sub-Saharan Africa documents how the underdeveloped financial markets lead to lack of credit for starting investment or for working capital by entrepreneurs. Fafchamps (2004) also shows that most firms in Sub-Saharan African countries are small and fail to grow to medium and large scale mainly due to a shortage of formal credit to expand investment. See also Bigsten, et al (2003).
} 
associated with remittance inflows.

The paper is organized as follows. We first outline the model in section 2. In section 3 we calibrate and simulate both the model with a foreign exchange constraint and the standard model to see which model better corresponds with the stylized facts and empirical evidence from previous works on lowincome economies and, in particular, on SSA. Section 4 concludes.

\section{The model}

The model in this paper builds extensively on work of Gali and Monacelli (2005) that lays out the structure of a basic small open economy New Keynesian DSGE model which is also discussed in Gali (2008). This basic model has been extended to account for incomplete pass-through (Monacelli, 2005), and multi-sector production (i.e., distinction between tradable and non-tradable production) (Santacreu, 2005). The empirical fit of different variants of the open economy New Keynesian DSGE models is investigated by Matheson (2010). The notations and structure of the model in this paper follow that of Santacreu (2005) and Matheson (2010), with the main differences being our assumption about the nature of the production function and the foreign exchange constraint in the non-tradable sector. Furthermore, the price differential between the non-tradable goods sector and the tradable goods sector (which can be referred to as the terms of trade of the former sector relative to the latter) that appears in our model does not appear in the aforementioned works.

\subsection{Preferences}

There is a representative, infinitely lived household that maximizes intertemporal utility subject to an intertemporal budget constraint. The household maximizes the following objective function:

$$
E_{0} \sum_{t=0}^{\infty} \beta^{t} U_{t}
$$

where $E$ is the expectation operator and $\beta$ is the subjective discount factor of the households. We assume that the representative household has an isoelastic instantaneous utility function and derives utility from consumption of composite goods and leisure:

$$
U_{t}=\frac{\left(C_{t}-h C_{t-1}\right)^{1-\sigma}}{1-\sigma}-\eta \frac{\left(L_{t}\right)^{1+\varphi}}{1+\varphi}
$$

where $C_{t}$ and $L_{t}$, respectively, represent household consumption and labour time supplied to market activities. $\sigma$ is the inverse of the elasticity of intertemporal substitution in consumption, $h$ the coeffi- 
cient of habit persistence, $\varphi$ the inverse of the elasticity of labour supply and $\eta$ the marginal disutility (utility cost) of participating in the labour market.

Consumption $C_{t}$ is a composite good consisting of tradable and non-tradable goods that can be given by the following CES aggregator:

$$
C_{t}=\left[\left(1-\gamma_{1}\right)^{\frac{1}{\theta_{1}}} C_{T, t}^{\frac{\left(\theta_{1}-1\right)}{\theta_{1}}}+\gamma_{1}^{\frac{1}{\theta_{1}}} C_{N, t}^{\frac{\left(\theta_{1}-1\right)}{\theta_{1}}}\right]^{\theta_{1} /\left(\theta_{1}-1\right)}
$$

where $C_{T, t}, C_{N, t}$ denote consumption of tradable and non-tradable goods, respectively. The parameter $\theta_{1}$ measures the elasticity of intratemporal substitution of consumption between tradable and nontradable goods. Larger value of $\theta_{1}$ implies that the goods are substitutes (with $\theta_{1} \longrightarrow \infty$ the goods become closer substitutes). $\gamma_{1}$ measures the proportion of non-tradable goods in the consumption of households. The representative household aims at maximizing the utility from consumption of both tradable and non-tradable goods by minimizing the expenditure on these two varieties while maintaining a certain target level of consumption. Solving this problem of optimal allocation of expenditure on tradable and non-tradable goods yields the following demand functions for these goods:

$$
\begin{gathered}
C_{T, t}=\left(1-\gamma_{1}\right)\left(\frac{P_{T, t}}{P_{t}}\right)^{-\theta_{1}} C_{t} \\
C_{N, t}=\gamma_{1}\left(\frac{P_{N, t}}{P_{t}}\right)^{-\theta_{1}} C_{t}
\end{gathered}
$$

where $P_{T, t}, P_{N, t}, P_{t}$ are the price indices of tradable, non-tradable and overall consumer goods, respectively. Both tradable and non-tradable goods are composite indices that are bundles of differentiated products as in monopolistically competitive markets. Hence, the composite consumption index of these goods can be given by the Dixit-Stiglitz aggregator

$$
\begin{aligned}
C_{T, t} & =\left[\int_{0}^{1}\left(C_{T, t,(j)}\right)\left(\frac{\zeta-1}{\zeta}\right) d j\right]^{\zeta /(\zeta-1)} \\
C_{N, t} & =\left[\int_{0}^{1}\left(C_{N, t,(j)}\right)\left(\frac{\zeta-1}{\zeta}\right) d j\right]^{\zeta /(\zeta-1)}
\end{aligned}
$$

where $j$ represents each variety in tradable and non-tradable goods while $\zeta$ is the elasticity of substitution between the differentiated goods or the varieties. The overall consumer price index is given by

$$
P_{t}=\left[\left(1-\gamma_{1}\right)\left(P_{T, t}\right)^{1-\theta_{1}}+\gamma_{1}\left(P_{N, t}\right)^{1-\theta_{1}}\right]^{1 /\left(1-\theta_{1}\right)}
$$

The tradable goods consumed domestically are either domestically produced or imported from the rest of the world. Hence, the consumption of tradables is determined as a CES index composed of 
home produced tradables and imports as follows:

$$
C_{T, t}=\left[\left(1-\gamma_{2}\right)^{\frac{1}{\theta_{2}}}\left(C_{H, t}\right)^{\frac{\left(\theta_{2}-1\right)}{\theta 2}}+\left(\gamma_{2}\right)^{\frac{1}{\theta_{2}}}\left(C_{F, t}\right)^{\frac{\left(\theta_{2}-1\right)}{\theta_{2}}}\right]^{\theta_{2} /\left(\theta_{2}-1\right)}
$$

The parameter $\theta_{2}$ measures the elasticity of intratemporal substitution of consumption between domestically produced tradable goods $C_{H, t}$ and imported goods $C_{F, t} \cdot \gamma_{2}$ denotes the share of imported goods in the total consumption of tradable goods consumed domestically. As with the case of total consumption above, expenditure minimization on the tradable goods yields the demand functions for domestically produced and imported tradables as in the following equations.

$$
\begin{gathered}
C_{H, t}=\left(1-\gamma_{2}\right)\left(\frac{P_{H, t}}{P_{T, t}}\right)^{-\theta_{2}} C_{T, t} \\
C_{F, t}=\gamma_{2}\left(\frac{P_{F, t}}{P_{T, t}}\right)^{-\theta_{2}} C_{T, t}
\end{gathered}
$$

where $P_{H, t}, P_{F, t}$ are, respectively, prices of domestically produced tradables and imported goods. The tradable goods price index is given by

$$
P_{T, t}=\left[\left(1-\gamma_{2}\right)\left(P_{H, t}\right)^{1-\theta_{2}}+\gamma_{2}\left(P_{F, t}\right)^{1-\theta_{2}}\right]^{\frac{1}{\left(1-\theta_{2}\right)}}
$$

Total consumption expenditure by households is given by the sum of the expenditures on tradable and non-tradable goods they consume

$$
P_{t} C_{t}=P_{T, t} C_{T, t}+P_{N, t} C_{N, t}=P_{F, t} C_{F, t}+P_{H, t} C_{H, t}+P_{N, t} C_{N, t}
$$

The households in this model own the firms in the economy and hence earn dividends. They also earn wage income from the supply of their labour. In this model, as is the case in most works in this area, there is no investment and therefore no rental income from capital services. For the sake of simplicity, we ignore the banking sector; like most authors in this field, we assume that households directly lend to the public sector. In reality, in most countries the domestic bonds issued by governments are held by financial institutions (commercial banks and insurance companies) not by households. Since the banking sector collects the deposits of households and lends to the public sector, our assumption ignores one channel in the dynamics of the economy. Therefore, the households try to maximize their lifetime utility subject to a sequence of budget constraints of the form:

$$
P_{t} C_{t}+B_{t} \leq W_{t} L_{t}+D_{t}+R_{t-1} B_{t-1}
$$

where $R_{t-1}$ is gross nominal return on bonds (i.e, it is 1 plus the nominal interest rate). This budget constraint implies that the household expenditure, as given by the left hand-side, consists of expenditure on consumption $C_{t}$, and purchase of public bonds, $B_{t}$. The flow of income, as given by the 
right-hand-side of the budget constraint, is composed of dividends, $D_{t}$, wage income from labour services, and receipt of principal and interest income on the bond held in the previous period, $B_{t-1}$.

The optimization problem faced by the representative household can now be summarized by the following Lagrange function:

$$
\underset{C_{t}, L_{t}, B_{t}}{\operatorname{Max}} \sum_{t=0}^{\infty} \beta^{t}\left\{\begin{array}{l}
\frac{\left(C_{t}-h C_{t-1}\right)^{1-\sigma}}{1-\sigma}-\eta \frac{\left(L_{t}\right)^{1+\varphi}}{1+\varphi} \\
-\lambda_{t}\left[P_{t} C_{t}+B_{t}-D_{t}-W_{t} L_{t}-R_{t-1} B_{t-1}\right]
\end{array}\right\}
$$

The first order conditions of the optimization problem of this household are given by

$$
\begin{gathered}
\left(C_{t}-h C_{t-1}\right)^{-\sigma}=\lambda_{t} P_{t} \\
\eta\left(L_{t}\right)^{\varphi}=\lambda_{t} W_{t} \\
\beta E_{t} \lambda_{t+1} R_{t}=\lambda_{t}
\end{gathered}
$$

Conditions (2.16) and (2.17) can be combined to give the marginal rate of substitution between consumption and labour while (2.18) is the famous Euler equation of consumption.

To prepare the model for numerical solution and ease the derivations in subsequent sections, we log-linearize some of the model equations introduced so far. To do so, we need a point around which log-linearization is performed. Hence, we assume that there exists a unique steady-state of the original model economy and replace the model equations by first order Taylor approximation around this steady-state. ${ }^{3}$

The total consumption index in (2.3) can be log-linearized to yield

$$
c_{t}=\left(1-\gamma_{1}\right) c_{T, t}+\gamma_{1} c_{N, t}
$$

Likewise, the log-linearized versions of the overall price index, consumption of tradable goods and price index of tradable goods are, respectively, given by

$$
\begin{gathered}
p_{t}=\left(1-\gamma_{1}\right) p_{T, t}+\gamma_{1} p_{N, t} \\
c_{T, t}=\left(1-\gamma_{2}\right) c_{H, t}+\gamma_{2} c_{F, t} \\
p_{T, t}=\left(1-\gamma_{2}\right) p_{H, t}+\gamma_{2} p_{F, t}
\end{gathered}
$$

\footnotetext{
${ }^{3}$ Note that all lower-cases indicate log-deviation from steady state, i.e., $x_{t}=\ln X_{t}-\ln \bar{X}$ where $\bar{X}$ is the steady state value of $X$.
} 
Further more, the equations of demand for tradable goods, non-tradable goods, domestically produced tradable and imported goods are log-linearized to yield the following:

$$
\begin{gathered}
c_{N, t}=-\theta_{1}\left(p_{N, t}-p_{t}\right)+c_{t} \\
c_{H, t}=-\theta_{2}\left(p_{H, t}-p_{T, t}\right)+c_{T, t} \\
c_{F, t}=-\theta_{2}\left(p_{F, t}-p_{T, t}\right)+c_{T, t}
\end{gathered}
$$

The optimality conditions of the representative household in (2.16)-(2.18) can be log-linearized to give the following equations.

$$
\begin{gathered}
\varphi l_{t}+\frac{\sigma}{1-h}\left(c_{t}-h c_{t-1}\right)=w_{t}-p_{t} \\
c_{t}=\frac{h}{1+h} c_{t-1}+\frac{1}{1+h} E_{t} c_{t+1}-\frac{1-h}{\sigma(1+h)}\left(r_{t}-E_{t} \pi_{t+1}\right)
\end{gathered}
$$

where $\pi_{t+1}$ is next period's overall inflation in the economy defined as $p_{t+1}-p_{t}$. These equations (i.e., (2.26) and (2.27)) are the marginal rate of substitution between consumption and labour and the consumption Euler equation of the household in log-linearized form.

\subsection{The real exchange rate, the terms of trade, and incomplete pass-through}

One of the developments in open economy New Keynesian DSGE models is the modeling of the deviation of prices from the Law of One Price referred to as the Law of One Price Gap (Monacelli, 2005:1051). The claim is that the domestic market for imported goods is characterized by monopolistic competition where firms have some power on the prices of goods they import and distribute. This market power creates a distortion resulting into a difference between the domestic and foreign prices of imported goods when expressed in terms of the same currency. It is assumed that the Law of One Price holds at the border and the distortion comes in as the importing firms try to exercise their power to derive their optimal price, as will be discussed in section 2.5.2 below ${ }^{4}$. It is this distortion that is referred to as the Law of One Price Gap - the tendency of prices to deviate from the Law of One Price. In simple words, the Law of one price gap means that the Law of one price fails to hold. This Law of one price gap is given by the ratio of the foreign price index in terms of domestic currency to the domestic currency price of imports

$$
\Psi_{t}=\frac{\varepsilon_{t} P_{t}^{*}}{P_{F, t}}
$$

\footnotetext{
${ }^{4}$ There are also other arguments for the deviation of the prices from the Law of One Price. For example, Mkrtchyan, et al (2009) discuss how the inefficiencies of domestic retail firms that distribute imported goods results into the distortion and hence deviation of prices from LOP.
} 
where $\varepsilon_{t}$ and $P_{t}^{*}$ are the nominal exchange rate and the price index of the rest of the world, respectively. The nominal exchange rate is defined as the domestic currency price of a unit of foreign currency. $P_{F, t}$ is the average price of imported goods in terms of domestic currency. Note that if the law of one price holds $\Psi_{t}$ is identically equal to unity. It is also worth mentioning that, throughout this paper, we assume that the Law of One Price holds for exports. This is reasonable assumption given the export structure of SSA economies and their share in international markets. Both features imply that these economies are price takers in international markets for their exports.

The real exchange rate is given as the ratio of the price index of the rest of the world (in terms of domestic currency) to the domestic price index:

$$
Q_{t}=\frac{\varepsilon_{t} P_{t}^{*}}{P_{t}}
$$

Another important relationship is the terms of trade of the domestic economy which measures the competitiveness of the economy. The terms of trade of the domestic economy is defined as the export price (price of domestically produced tradable goods) relative to the domestic currency price of imports.

$$
V_{t}=\frac{P_{H, t}}{P_{F, t}}
$$

Hence, increasing terms of trade indicates improvement of the competitiveness of the economy in the international market.

We can derive some links between these quantities that are of use in the following sections. Loglinearizing (2.28) around symmetric steady-state (simultaneous steady-state at both domestic economy and the economy of the rest of the world) and subtracting one period lag we obtain the equation of the evolution of the Law of one price gap

$$
\psi_{t}-\psi_{t-1}=e_{t}-e_{t-1}+\pi_{t}^{*}-\pi_{F, t}
$$

Similarly, log-linearizing (2.29) yields

$$
q_{t}=e_{t}+p_{t}^{*}-p_{t}
$$

Replacing $p_{t}$ by (2.20) and using the Law of one price gap (in log-linearized form) to replace $e_{t}+p_{t}^{*}$, the log-linearized equation of the real exchange rate can be written as

$$
q_{t}=\psi_{t}+p_{F, t}-\left(1-\gamma_{1}\right) p_{T, t}-\gamma_{1} p_{N, t}=e_{t}+p_{t}^{*}-p_{T, t}+\gamma_{1} p_{T, t}-\gamma_{1} p_{N, t}
$$

Again replacing $p_{T, t}$ by $(2.22)$ we have

$$
q_{t}=\psi_{t}+p_{F, t}-\left[\left(1-\gamma_{2}\right) p_{H, t}+\gamma_{2} p_{F, t}\right]+\gamma_{1}\left[\left(1-\gamma_{2}\right) p_{H, t}+\gamma_{2} p_{F, t}\right]-\gamma_{1} p_{N, t}
$$


Employing the definition of the terms of trade (in log-linearized form) we obtain the following loglinearized equation of the real exchange rate:

$$
q_{t}=\psi_{t}-\left(1-\gamma_{2}\left(1-\gamma_{1}\right)\right) v_{t}-\gamma_{1}\left(p_{N, t}-p_{H, t}\right)
$$

This implies that the percentage deviation of the real exchange rate from its steady state value depends on three factors. These are the deviation of the law of one price gap from its steady state, the deviation of the terms of trade from its steady state and the relative deviations of the prices of domestically produced tradable and non-tradable goods. The deviation of the Law of one price gap from its steady state depends on three factors - the nominal exchange rate, the foreign price index, and the price index of imports. Likewise, the deviation of terms of trade from its steady state depends on the relative deviations of prices of imports and prices of domestically produced tradable goods. ${ }^{5}$

From (2.32) above we can also derive the equation showing the evolution of nominal exchange rate by subtracting the lags of the variables involved

$$
e_{t}=e_{t-1}+q_{t}-q_{t-1}-\pi_{t}^{*}+\pi_{t}
$$

which shows that the nominal exchange rate appreciates with foreign inflation and depreciates with local inflation.

\subsection{International risk sharing and the uncovered interest parity condition}

One of the assumptions made in the open economy models is that economic agents have access to the complete set of internationally traded securities. Hence, according to this assumption, there is international risk sharing. This assumption plays an important role in linking domestic consumption with that of the rest of the world and is a necessary condition to establish the stationarity of the model. This assumption is very bold and unrealistic to make for low income economies. However, we defer the modification of this assumption to subsequent work for two reasons. First, the main aim of this paper is to assess whether the introduction of the foreign exchange constraint in the production process gives different dynamics of macroeconomic variables than the standard model. Since the assumption of international risk sharing is employed in the standard models, comparison of results will be easier if this assumption is maintained. Second, the alternative to this assumption is to assume that economic agents face incomplete asset markets. One such assumption is to introduce a debt dependent risk

\footnotetext{
${ }^{5}$ Note that in Matheson (2010) this last relationship in (2.33) is unjustifiably missing - in his paper there is only the deviation of the non-tradable goods price index from its steady state.
} 
premium where the interest rate faced by domestic economy increases with the net debt owed by the country (see, for example, Eicher, et al (2008)). Schmitt-Grohe and Uribe (2003:165) have shown, however, that various models with complete and incomplete asset markets yield "identical dynamics at business cycle frequencies". Hence, according to Schmitt-Grohe and Uribe (2003) the choice of one variant over the other is merely a computational convenience.

As mentioned earlier, the assumption of international risk sharing links domestic consumption with the consumption level of the rest of the world. This link between domestic consumption and that of the rest of the world can be derived using the consumption Euler equation derived for the domestic households in (2.27) which can be rewritten as

$$
\beta E_{t} \frac{\lambda_{t+1}}{\lambda_{t}}=\frac{1}{R_{t}} \text { implies that } \beta E_{t} \frac{\left(C_{t+1}-h C_{t}\right)^{-\sigma}}{\left(C_{t}-h C_{t-1}\right)^{-\sigma}} \frac{P_{t}}{P_{t+1}}=\frac{1}{R_{t}}
$$

Since agents in the rest of the world have access to the same set of bonds, their Euler equation can also be given by the following equation (assuming that agents in the domestic economy and the rest of the world have the same preferences)

$$
\beta E_{t} \frac{\left(C_{t+1}^{*}-h C_{t}^{*}\right)^{-\sigma}}{\left(C_{t}^{*}-h C_{t-1}^{*}\right)^{-\sigma}} \frac{\varepsilon_{t} P_{t}^{*}}{\varepsilon_{t+1} P_{t+1}^{*}}=\frac{1}{R_{t}}
$$

This implies that

$$
\beta E_{t} \frac{\left(C_{t+1}-h C_{t}\right)^{-\sigma}}{\left(C_{t}-h C_{t-1}\right)^{-\sigma}} \frac{P_{t}}{P_{t+1}}=\beta E_{t} \frac{\left(C_{t+1}^{*}-h C_{t}^{*}\right)^{-\sigma}}{\left(C_{t}^{*}-h C_{t-1}^{*}\right)^{-\sigma}} \frac{\varepsilon_{t} P_{t}^{*}}{\varepsilon_{t+1} P_{t+1}^{*}}
$$

or

$$
\left(C_{t}-h C_{t-1}\right)=E_{t} \frac{\left(C_{t+1}-h C_{t}\right)}{Q_{t+1}^{\frac{1}{\sigma}}\left(C_{t+1}^{*}-h C_{t}^{*}\right)} Q_{t}^{\frac{1}{\sigma}}\left(C_{t}^{*}-h C_{t-1}^{*}\right)
$$

In equilibrium, according to Gali and Monacelli (2005), the following must hold

$$
\left(C_{t}-h C_{t-1}\right)=\chi Q_{t}^{\frac{1}{\sigma}}\left(C_{t}^{*}-h C_{t-1}^{*}\right)
$$

for all $t . \chi$ is a constant that depends on the relative initial conditions in asset holdings. For future reference, log-linearizing (2.37) around a symmetric steady-state, and assuming that $c_{t}^{*}=y_{t}^{*}$ (because the rest of the world is large economy rlative to the domestic economy, import or export of the domestic economy is negligible and one can safely assume the rest of the world as a closed economy when modeling the small open economy), we obtain

$$
c_{t}-h c_{t-1}=c_{t}^{*}-h c_{t-1}^{*}+\frac{(1-h)}{\sigma} q_{t}=y_{t}^{*}-h y_{t-1}^{*}+\frac{(1-h)}{\sigma} q_{t}
$$

The assumption of complete asset markets allows to derive the link between the domestic and foreign interest rates through the uncovered interest parity condition. Assuming, as before, that domestic 
and foreign economic agents have the same preferences, the consumption Euler equation of the rest of the world can be given by

$$
\beta E_{t} \frac{\left(C_{t+1}^{*}-h C_{t}^{*}\right)^{-\sigma}}{\left(C_{t}^{*}-h C_{t-1}^{*}\right)^{-\sigma}} \frac{P_{t}^{*}}{P_{t+1}^{*}}=\frac{1}{R_{t}^{*}}
$$

Log-linearizing around a steady-state gives

$$
\frac{\sigma}{1-h}\left[\left(E_{t} c_{t+1}^{*}-h c_{t}^{*}\right)-\left(c_{t}^{*}-h c_{t-1}^{*}\right)\right]=\left(r^{*}-E_{t} \pi_{t+1}^{*}\right)
$$

The same relationship can be derived for domestic households from the Euler equation in (2.26) as

$$
\frac{\sigma}{1-h}\left[\left(E_{t} c_{t+1}-h c_{t}\right)-\left(c_{t}-h c_{t-1}\right)\right]=\left(r-E_{t} \pi_{t+1}\right)
$$

Subtracting (2.40) from (2.41) and using (2.38) and the definition of real exchange rate gives

$$
\begin{aligned}
& \left(r-E_{t} \pi_{t+1}\right)-\left(r^{*}-E_{t} \pi_{t+1}^{*}\right) \\
& =\frac{\sigma}{(1-h)}\left[\left(E_{t} c_{t+1}-h c_{t}\right)-\left(c_{t}-h c_{t-1}\right)-\left(E_{t} c_{t+1}^{*}-h c_{t}^{*}\right)-\left(c_{t}^{*}-h c_{t-1}^{*}\right)\right] \\
& =\left(E_{t} q_{t+1}-q_{t}\right) \\
& r-r^{*}=E_{t} q_{t+1}-E_{t} p_{t+1}^{*}+E_{t} p_{t+1}-\left(q_{t}-p_{t}^{*}+p_{t}\right) \\
& E_{t} q_{t+1}=q_{t}+r-r^{*}+E_{t} \pi_{t+1}^{*}-E_{t} \pi_{t+1}
\end{aligned}
$$

or

$$
E_{t} e_{t+1}=e_{t}+r-r^{*}
$$

This equation shows that expected rate of appreciation/depreciation of the domestic currency is determined by the difference between the nominal interest rates of domestic economy and that of the rest of the world. With this we turn to the production side of the economy.

\section{$2.4 \quad$ Firms}

The economy produces two types of commodities where one type of commodity is a tradable product and the other a non-tradable commodity. But unlike the standard model we explicitly model the importance of foreign exchange in the production of the non-tradable commodity. As discussed in the previous section, this argument is in line with the literature that reports production in developing countries is highly dependent on the capacity of the economies to import intermediate inputs and capital. To this effect, we introduce the availability of foreign exchange as an additional constraint faced by firms, as in the CIA type framework where the import of intermediate inputs that determine 
production is constrained by the availability of foreign exchange. The tradable goods are primary or semi-processed commodities produced by a continuum of identical monopolistically competitive firms using capital, labour and land (natural resources). Likewise, non-tradable goods are produced by a continuum of identical monopolistically competitive firms that use capital, labour and intermediate inputs. This specification is identical to that of Kose (2002) and Kose and Reizman (2001) discussed in the earlier sections of this paper. The main difference in our model is that we introduce a constraint specifying that the supply of intermediate goods that determine production of non-traded goods depends on the availability of foreign exchange, which in turn depends on the export earnings of the country and its access to international financial/asset markets. For simplicity, we assume that capital and labour are homogenous and there is free mobility of both inputs in the economy. This implies that we have the same wage and rental rate of capital in both tradable and non-tradable sectors.

\subsubsection{Production of tradable goods}

As discussed above, firms producing tradable goods use labour $L$, capital $K$, and land (natural resource) $N$ to produce tradable goods. However, capital does not appear in our model for the sake of simplicity and following the tradition of the New Keynesian DSGE models. This tradition of ignoring capital when dealing with short-run fluctuations is based on empirical evidence. That is, studies show that the endogenous variation of the capital stock has little relationship with output variations at business cycle frequencies (McCallum and Nelson, 1999 cited in Walsh, 2010). In addition, assuming that the total size/quantity of land/natural resources is fixed and fully employed, we ignore it, too, in the production function.

Hence, assuming a linear technology, the firms in the tradable sector have the following production function

$$
Y_{H, t}=Z_{H, t} L_{H, t}
$$

$Z_{H, t}$ represents total factor productivity the logarithm of which is assumed to follow a first-order autoregressive process as follows:

$$
\ln Z_{H, t}=\rho_{H} \ln Z_{H, t-1}+\epsilon_{H, t}, 0<\rho_{H}<1 .
$$

where $\epsilon_{H, t}$ is an i.i.d normal error term with zero mean and a standard deviation of $\sigma_{\epsilon H}$.

The objective of a representative firm in this sector can be given as minimizing the cost of pro- 
duction given the production level:

$$
\operatorname{Min}_{L_{H, t}}\left(\frac{W_{t} L_{H, t}}{P_{H, t}}\right) \text { s.t } Y_{H, t}=Z_{H, t} L_{H, t}
$$

The first order condition of the problem yields the expression for the marginal cost of firms producing domestic tradable goods:

$$
M C_{H, t}=\frac{W_{t}}{P_{H, t} Z_{H, t}}
$$

which can be log-linearized to give

$$
m c_{H, t}=w_{t}-p_{H, t}-z_{H, t}
$$

Subtracting and adding $p_{t}$ to the right hand side of (2.46) above and using (2.26) we obtain

$$
m c_{H, t}=\varphi l_{t}+\frac{\sigma}{1-h}\left(c_{t}-h c_{t-1}\right)-z_{H, t}+p_{t}-p_{H, t}
$$

Using the fact that $p_{t}=\left(1-\gamma_{1}\right) p_{T, t}+\gamma_{t} p_{N, t}$ and $p_{T, t}=\left(1-\gamma_{2}\right) p_{H, t}+\gamma_{2} p_{F, t}$ the log-linearized real marginal cost of firms in the tradable goods sector is given by

$$
m c_{H, t}=\varphi l_{t}+\frac{\sigma}{1-h}\left(c_{t}-h c_{t-1}\right)-z_{H, t}-\gamma_{2}\left(1-\gamma_{1}\right) v_{t}+\gamma_{1}\left(p_{N, t}-p_{H, t}\right)
$$

This implies that in an open economy the marginal cost is influenced by more factors. In addition to the cost of inputs and level of productivity, as in the closed economy, the marginal cost in the domestic tradable sector is determined by the terms of trade of the economy and the price differential between tradable and non-tradable sectors.

\subsubsection{Production of non-tradable goods}

The firms in this sector employ labour $L$, capital $K$ and imported intermediate inputs, $M$, to produce non-tradable goods that are consumed domestically. The production function is a simple Cobb-Douglas type with constant returns to scale with respect to all three inputs but decreasing returns with respect to increases in any two of the inputs:

$$
Y_{N, t}=Z_{N, t} L_{N, t}^{\alpha_{1}} M_{t}^{\alpha_{2}} K^{\alpha_{3}},\left(\alpha_{1} \geq 0, \alpha_{2} \geq 0, \alpha_{3} \geq 0, \alpha_{1}+\alpha_{2}+\alpha_{3}=1\right)
$$

where $Y_{N, t}$ denotes the output level of the non-tradable goods and $Z_{N, t}$ is total factor productivity in the non-tradable goods sector of the economy. Again for the reasons discussed before, we ignore the capital stock (i.e., equate the capital stock to unity). As in the tradable goods sector, we assume that the total factor productivity follows a first-order autoregressive process in logs. 


$$
\ln Z_{N, t}=\rho_{N} \ln Z_{T, t-1}+\epsilon_{N, t}, 0<\rho_{N}<1 .
$$

where again $\epsilon_{N, t}$ is an i.i.d error term with zero mean and standard deviation of $\sigma_{\epsilon N}$.

As discussed repeatedly in the previous sections, in this economy firms in the non-tradable sector face a foreign exchange constraint for the purchase of intermediate inputs. We introduce this constraint as

$$
\frac{P_{F, t} M_{t}}{\varepsilon_{t}} \leq \Omega_{t}
$$

where $P_{F, t}, M_{t}, \varepsilon_{t}$ are the average price level of imported goods in terms of domestic currency, imported intermediate inputs, and the nominal exchange rate, respectively, as defined in the previous sections. $\Omega_{t}$ denotes the quantity of foreign exchange available at the beginning of period $t$ to import intermediate inputs for production during that period. This stock of foreign exchange, in turn, evolves according to the following equation of motion:

$$
\begin{aligned}
\Omega_{t} & =\Omega_{t-1}+P_{X, t-1} X_{t-1}+F_{t-1}+A_{t-1}+R E M_{t-1} \\
& -\left(1+r_{t-2}^{*}+\xi\left(\frac{F_{t-2}}{P_{t-2} K_{t-2}}\right)\right) F_{t-2}-\frac{P_{F, t-1}}{e_{t-1}}\left(C_{F, t-1}+M_{t-1}\right)
\end{aligned}
$$

where $X_{t}$ and $P_{X, t}$ are export and foreign currency price of export, respectively, while $F, A$, and $R E M$ are, respectively, foreign loan, foreign aid and remittances. $r^{*}$ is the foreign nominal interest rate, $\xi$ captures the risk perception of foreigners about the domestic economy, and $K$ is the capital stock of the domestic economy. Note that this equation indicates that the domestic economy faces higher cost of borrowing as the risk perception increases and/or the debt capital stock ratio increases (Eicher, et al 2008).

Since the novelty of this study lies in the introduction of foreign exchange constraint (2.50), it is imperative to discuss the processes that determine this constraint in some detail. As indicated in (2.50), the amount of imported intermediate inputs that firms can employ during a given period, expressed in foreign currency, is determined by the amount of foreign currency available at the beginning of the period. The stock of foreign currency available, in turn, is the result of many endogenous and exogenous events that took place in the previous period and beyond, as expressed in (2.51). Factors that affect the availability of this foreign exchange positively include the previous period's inflow of foreign exchange from export revenue, $P_{X, t-1} X_{t-1}$, foreign loan, $F_{t-1}$, official development assistance 
or foreign aid, $A_{t-1}$, remittances, $R E M_{t-1}$, and the stock of foreign exchange available at the beginning of previous period, which itself is the result of the interplay of the same factors in the past. On the other hand, repayment of the principal, interest and premium on foreign debt and import of consumption goods and intermediate inputs during the previous period negatively affect the quantity available for the current period. In general, poor performance of the external sector of the economy in the previous period, and periods before, affects the performance of the economy during the current period as well as in future periods. This substantiates our argument in previous sections that incorporating the availability of foreign exchange when modeling the macroeconomy of low income countries enriches the dynamics.

However, employing (2.51) poses some analytical difficulty in the process of log-linearizing the model for numerical solution. That is, in order to loglinearize (2.51) we need to obtain the steady state ratios of all the arguments to the stock of foreign exchange $\left(\Omega_{t}\right)$. This can be done when modeling a specific economy instead of the general case analyzed in this paper. Therefore, for the sake of analytical convenience, we assume that at time $t$ the quantity of foreign exchange available for the importers of intermediate inputs is a certain proportion of the export earnings of the economy. That is, in each period the central bank sells some proportion of foreign currency inflows to firms importing intermediate inputs. Assuming that the foreign exchange constraint is binding, the relationship between import of intermediate inputs and export earnings can be approximated as

$$
\frac{P_{F, t} M_{t}}{\varepsilon_{t}}=\Omega_{t}=\vartheta P_{x, t} X_{t}=\vartheta P_{t}^{*} C_{H, t}^{*}
$$

where $\vartheta$, is some constant, $P_{t}^{*}$ overall price index of the rest of the world and $C_{H, t}^{*}$ is consumption by the rest of the world of domestically produced tradable goods (exports). We believe that this assumption simplifies the analysis and does not change the dynamics of the model significantly ${ }^{6}$. Again for future reference, log-linearizing (2.52) around a steady state yields

$$
m_{t}=e_{t}+p_{t}^{*}-p_{F, t}+c_{H, t}^{*}=\psi_{t}+c_{H, t}^{*}
$$

\footnotetext{
${ }^{6}$ It is important to admit that incorporating (2.51) in stead of (2.52) will have additional benefits as it captures almost all sources of financial shock that low income countries face. In an event of financial crisis, like the recent meltdown, countries face lower inflow of official development assistance, remittances, and face difficulty accessing foreign loan which reinforeces the impact of a crisis on their economic activity. The worsening economic activity, in turn, lowers the ability of the country to service its debt which leads to increasing interest rate and risk premium on new loans. Specifying the components of (2.51) captures all these effects and links them to production. However, as discussed in the text, employing (2.51) directly requires obtaining the steady state ratios of all the arguments to the stock of foreign exchange $\left(\Omega_{t}\right)$ in order to log-linearize the model. For the purpose of this paper, however, the simplification is appropriate.
} 
As can be seen from the discussions in the next section, $c_{H, t}^{*}$ is a function of the terms of trade of the domestic economy, the real exchange rate, foreign income, and the price differential between the tradable and non-tradable sectors of the domestic economy. This implies that the availability of foreign exchange or the imported intermediate input depends on the performance of the economy of the rest of the world (as reflected in foreign income) and the competitiveness of the domestic economy.

The objective of a representative firm in this sector can be given as minimizing the cost of production given the production level:

$$
\operatorname{Min}_{L_{N, t}, M_{t}}\left(W_{t} L_{N, t}+P_{F, t} M_{t}\right) \text { s.t } Y_{N, t}=Z_{N, t} L_{N, t}^{\alpha_{1}} M_{t}^{\alpha_{2}}
$$

Solving this problem for $L_{N, t}$ and $M_{t}$ we obtain the conditional demand functions for these inputs from which the real total cost as a function of input prices, output price, total factor productivity and output can be derived. From the total cost, the marginal cost (in real terms) is derived as

$$
M C_{N, t}=\frac{1}{\alpha_{1}+\alpha_{2}}\left[\left(\frac{\alpha_{2}}{\alpha_{1}}\right)^{\frac{\alpha_{1}}{\alpha_{1}+\alpha_{2}}}+\left(\frac{\alpha_{2}}{\alpha_{1}}\right)^{\frac{-\alpha_{2}}{\alpha_{1}+\alpha_{2}}}\right]\left(\frac{W_{t} L_{N, t}}{P_{N, t} Y_{N, t}}\right)^{\frac{\alpha_{1}}{\alpha_{1}+\alpha_{2}}}\left(\frac{P_{F, t} M_{t}}{P_{N, t} Y_{N, t}}\right)^{\frac{\alpha_{2}}{\alpha_{1}+\alpha_{2}}}
$$

which can be log-linearized to yield

$$
m c_{N, t}=\frac{1}{\alpha_{1}+\alpha_{2}}\left[\alpha_{1}\left(w_{t}+l_{N, t}-p_{N, t}-y_{N, t}\right)+\alpha_{2}\left(p_{F, t}+m_{t}-p_{N, t}-y_{N, t}\right)\right]
$$

As with the tradable goods sector adding and subtracting $p_{t}$ and $p_{H, t}$ to the two terms in the right hand side of the above equation and using the log-linearized marginal rate of substitution between consumption and labour supply we obtain

$$
\begin{aligned}
m c_{N, t} & =\frac{1}{\alpha_{1}+\alpha_{2}}\left[y_{N, t}-z_{N, t}-\alpha_{2} m_{t}\right. \\
& +\alpha_{1}\left(\varphi l_{t}+\frac{\sigma}{1-h}\left(c_{t}-h c_{t-1}\right)-y_{N, t}-\gamma_{2}\left(1-\gamma_{1}\right) v_{t}+\left(\gamma_{1}-1\right)\left(p_{N, t}-p_{H, t}\right)\right) \\
& \left.+\alpha_{2}\left(m_{t}-v_{t}-y_{N, t}-\left(p_{N, t}-p_{H, t}\right)\right)\right]
\end{aligned}
$$

The above expression indicates that the marginal cost in the non-tradable sector is driven positively by the inputs of production and negatively by the terms of trade.

\subsection{Price setting}

\subsubsection{Price setting by domestic producers}

One of the basic tenets of New Keynesian economics is that prices are not perfectly flexible in the short run. There are a plethora of reasons for the firm to charge a price level different from the optimal 
price level usually derived as a constant markup over the marginal $\operatorname{cost}^{7}$. One way of modeling this price rigidity is the staggered pricing à la Calvo (1983). According to Calvo, at a given point in time a random fraction $\epsilon_{i}$ of firms cannot adjust their prices while the remaining $1-\epsilon_{i}($ with $i=H, N)$ can do. However, we also assume that in both the tradable and non-tradable sectors of the economy those firms who can reset their prices are of two types - in the literature referred to as "forward-looking" and "backward - looking" firms. The forward-looking firms are those firms that re-set their prices according to the Calvo (1983) model. These firms tend to take into account that their prices will be fixed at the price level they are going to set now for some time to come. Hence, they consider all future losses that they incur as a result of this inability to adjust their prices when setting their prices at a given point in time. The backward-looking firms, on the other hand, set their prices based on rules of thumb using information about the historical development of the price level. Suppose random fractions $\varsigma_{H}$ and $\varsigma_{N}$ of firms in the tradable and non-tradable sectors, respectively, set their prices based on rules of thumb using their knowledge of the historical development of price levels (hence, backward looking). Likewise, fractions $\left(1-\varsigma_{H}\right)$ and $\left(1-\varsigma_{N}\right)$ of firms in the tradable and non-tradable sectors, respectively, set their prices according to the Calvo price setting. This process will give the hybrid New Keynesian Phillips Curve developed by Gali and Gertler $(1999)^{8}$. For domestically produced tradable goods, this equation is given by

$$
\pi_{H, t}=\kappa_{b, H} \pi_{H, t-1}+\kappa_{F, H} E_{t} \pi_{H, t+1}+\lambda_{H} m c_{H, t}
$$

where

$$
\begin{aligned}
\kappa_{b, H} & =\frac{\varsigma_{H}}{\epsilon_{H}+\varsigma_{H}\left(1-\epsilon_{H}(1-\beta)\right)}, \\
\kappa_{f, H} & =\frac{\beta \epsilon_{H}}{\epsilon_{H}+\varsigma_{H}\left(1-\epsilon_{H}(1-\beta)\right)}, \\
\lambda_{H} & =\frac{\left(1-\varsigma_{H}\right)\left(1-\epsilon_{H}\right)\left(1-\beta \epsilon_{H}\right)}{\epsilon_{H}+\varsigma_{H}\left(1-\epsilon_{H}(1-\beta)\right)} .
\end{aligned}
$$

Likewise, the inflation dynamics for the non-tadable sector can be given by the following hybrid New Keynesian Phillips Curve:

$$
\pi_{N, t}=\kappa_{b, N} \pi_{N, t-1}+\kappa_{F, N} E_{t} \pi_{N, t+1}+\lambda_{N} m c_{N, t}
$$

\footnotetext{
${ }^{7}$ The New Keynesian literature mentions different factors such as menu costs, aggregate demand externalities, staggered prices, coordination failure, etc (Snowdon and Vane, 2005: 357-432), that inhibit firms from automatically adjusting their prices in response to changes in economic conditions in the short run.

${ }^{8}$ For detailed derivations of the Hybrid New Keynesian Phillips Curve for small open economy, see Holmberg (2006).
} 
where

$$
\begin{aligned}
\kappa_{b, N} & =\frac{\varsigma_{N}}{\epsilon_{N}+\varsigma_{N}\left(1-\epsilon_{N}(1-\beta)\right)}, \\
\kappa_{F, N} & =\frac{\beta \epsilon_{N}}{\epsilon_{N}+\varsigma_{N}\left(1-\epsilon_{N}(1-\beta)\right)}, \\
\lambda_{N} & =\frac{\left(1-\varsigma_{N}\right)\left(1-\epsilon_{N}\right)\left(1-\beta \epsilon_{N}\right)}{\epsilon_{N}+\varsigma_{N}\left(1-\epsilon_{N}(1-\beta)\right)} .
\end{aligned}
$$

\subsubsection{Price setting by import firms}

The law of one price gap is an important element in deriving the inflation dynamics of imported goods. As a result of this law the price index of imports in domestic currency is no longer equal to the nominal exchange rate times the foreign price index. As with the domestic firms, we assume that the domestic market for imported goods is characterized by monopolistic competition. There are a continuum of firms importing and selling differentiated goods. Each firm in this market tries to maximize its profit by setting its optimal price, taking the demand for its product as given. Like the domestic producers, the importing firms also set their prices according to Calvo price adjustment. Accordingly, at a given point in time a random fraction $\epsilon_{F}$ of firms cannot adjust their prices while the remaining $1-\epsilon_{F}$ can do. However, we also assume that of those firms who can reset their prices some are "forward-looking" and others are "backward-looking" firms. Suppose the fraction $\varsigma_{F}$ of firms set their prices based on rules of thumb using their knowledge of the historical development of import price levels (hence, backward-looking) while the fraction $\left(1-\varsigma_{F}\right)$ of firms are "forward-looking" and set their prices according to the Calvo price setting. The rate of inflation in the average domestic currency price of imports will be given by the following equation:

$$
\pi_{F, t}=\kappa_{b, F} \pi_{F, t-1}+\kappa_{f, F} E_{t} \pi_{F, t+1}+\lambda_{F} \psi_{t}
$$

where

$$
\begin{aligned}
\kappa_{b, F} & =\frac{\varsigma_{F}}{\epsilon_{F}+\varsigma_{F}\left(1-\epsilon_{F}(1-\beta)\right)}, \\
\kappa_{f, F} & =\frac{\beta \epsilon_{F}}{\epsilon_{F}+\varsigma_{F}\left(1-\epsilon_{F}(1-\beta)\right)}, \\
\lambda_{F} & =\frac{\left(1-\varsigma_{F}\right)\left(1-\epsilon_{F}\right)\left(1-\beta \epsilon_{F}\right)}{\epsilon_{F}+\varsigma_{F}\left(1-\epsilon_{F}(1-\beta)\right)} .
\end{aligned}
$$

This implies that there are three factors that determine the inflation rate of the imported goods. The first two are the lagged and the expected future inflation rates - the magnitude of which depends on 
the fraction of the backward-looking (or the rule of thumb) and forward-looking firms in the import sector of the economy, respectively. The third factor is the law of one price gap.

Accordingly, the inflation dynamics of the tradable goods in the economy is given by the weighted average of the inflation in the home produced tradables and imported goods inflation and the weights are given by the proportion of these goods in the consumption of households as given by (2.22). Subtracting the lags from both sides of (2.22) gives the following equation of the inflation rate of tradable goods:

$$
\begin{gathered}
\pi_{T, t}=\left(1-\gamma_{2}\right) \pi_{H, t}+\gamma_{2} \pi_{F, t} \\
\pi_{T, t}=\pi_{H, t}-\gamma_{2}\left(\pi_{H, t}-\pi_{F, t}\right)=\pi_{H, t}-\gamma_{2}\left(v_{t}-v_{t-1}\right)
\end{gathered}
$$

Similarly, the overall inflation rate of the economy can be given by subtracting the lags from both sides of (2.14) which is the average of the inflation in tradable and non-tradable goods

$$
\pi_{t}=\left(1-\gamma_{1}\right) \pi_{T, t}+\gamma_{1} \pi_{N, t}
$$

\subsection{Goods market clearing conditions}

Goods market clearing in the domestic economy requires that domestic output is equal to the sum of domestic consumption and foreign consumption of domestically produced goods or exports. This implies

$$
Y_{t}=Y_{H, t}+Y_{N, t}=C_{H, t}+C_{H, t}^{*}+C_{N, t}
$$

We know that

$$
C_{H, t}=\left(1-\gamma_{2}\right)\left(\frac{P_{H, t}}{P_{T, t}}\right)^{-\theta_{2}} C_{T, t} \text { and, in turn, } C_{T, t}=\left(1-\gamma_{1}\right)\left(\frac{P_{T, t}}{P_{t}}\right)^{-\theta_{1}} C_{t}
$$

therefore we obtain

$$
C_{H, t}=\left(1-\gamma_{1}\right)\left(1-\gamma_{2}\right)\left(\frac{P_{H, t}}{P_{T, t}}\right)^{-\theta_{2}}\left(\frac{P_{T, t}}{P_{t}}\right)^{-\theta_{1}} C_{t}
$$

Log-linearizing (2.63) around a steady state, we obtain

$$
c_{H, t}=-\theta_{2}\left(p_{H, t}-p_{T, t}\right)-\theta_{1}\left(p_{T, t}-p_{t}\right)+c_{t}
$$

Using (2.20) and (2.22), this becomes

$$
\begin{aligned}
c_{H, t} & =-\theta_{2} p_{H, t}+\theta_{2}\left[\left(1-\gamma_{2}\right) p_{H, t}+\gamma_{2} p_{F, t}\right]-\theta_{1} p_{T, t} \\
& +\theta_{1} p_{T, t}-\theta_{1} \gamma_{1}\left[\left(1-\gamma_{2}\right) p_{H, t}+\gamma_{2} p_{F, t}\right]+\theta_{1} \gamma_{1} p_{N, t}+c_{t}
\end{aligned}
$$


Finally, using the definition of terms of trade (in log-linearized form) we find

$$
c_{H, t}=-\gamma_{2}\left(\theta_{2}-\theta_{1} \gamma_{1}\right) v_{t}+\theta_{1} \gamma_{1}\left(p_{N, t}-p_{H, t}\right)+c_{t}
$$

Given the domestic consumption of domestically produced tradable goods as

$$
C_{H, t}=\left(1-\gamma_{2}\right)\left(\frac{P_{H, t}}{P_{T, t}}\right)^{-\theta_{2}} C_{T, t}
$$

following Liu (2006) we argue that the foreign consumption of domestically produced tradable goods (exports) must be

$$
C_{H, t}^{*}=\gamma_{2}\left(\frac{P_{H, t}}{\varepsilon_{t} P_{t}^{*}}\right)^{-\theta_{2}} C_{t}^{*}=\gamma_{2}\left(\frac{P_{H, t}}{Q_{t} P_{t}}\right)^{-\theta_{2}} C_{t}^{*}
$$

Log-linearizing (2.65) gives

$$
c_{H, t}^{*}=-\theta_{2}\left(p_{H, t}-q_{t}-p_{t}\right)+c_{t}^{*}
$$

Replacing $p_{t}$ by $(2.20)$

$$
\begin{gathered}
c_{H, t}^{*}=-\theta_{2} p_{H, t}+\theta_{2} p_{t}+c_{t}^{*}+\theta_{2} q_{t} \\
c_{H, t}^{*}=-\theta_{2} p_{H, t}+\theta_{2}\left[\left(1-\gamma_{1}\right) p_{T, t}+\gamma_{1} p_{N, t}\right]+c_{t}^{*}+\theta_{2} q_{t} \\
c_{H, t}^{*}=-\theta_{2} p_{H, t}+\theta_{2} p_{T, t}-\theta_{2} \gamma_{1} p_{T, t}+\theta_{2} \gamma_{1} p_{N, t}+c_{t}^{*}+\theta_{2} q_{t}
\end{gathered}
$$

Then, replacing $p_{T, t}$ by $(2.22)$

$$
\begin{aligned}
c_{H, t}^{*}= & -\theta_{2} p_{H, t}+\theta_{2}\left[\left(1-\gamma_{2}\right) p_{H, t}+\gamma_{2} p_{F, t}\right]-\theta_{2} \gamma_{1}\left[\left(1-\gamma_{2}\right) p_{H, t}+\gamma_{2} p_{F, t}\right] \\
+ & \theta_{2} \gamma_{1} p_{N, t}+c_{t}^{*}+\theta_{2} q_{t} \\
c_{H, t}^{*} & =-\theta_{2} \gamma_{2} p_{H, t}+\theta_{2} \gamma_{2} p_{F, t}-\theta_{2} \gamma_{1} p_{H, t}+\theta_{2} \gamma_{1} \gamma_{2} p_{H, t}-\theta_{2} \gamma_{1} \gamma_{2} p_{F, t} \\
& +\theta_{2} \gamma_{1} p_{N, t}+c_{t}^{*}+\theta_{2} q_{t}
\end{aligned}
$$

Finally, using the definition of the terms of trade (in log-linearized form) we obtain

$$
c_{H, t}^{*}=-\theta_{2} \gamma_{2}\left(1-\gamma_{1}\right) v_{t}+\theta_{2} \gamma_{1}\left(p_{N, t}-p_{H, t}\right)+c_{t}^{*}+\theta_{2} q_{t}
$$

In the non-tradable sector the market clearing condition is given by the equality of production and consumption which can be given in log-linearized form as

$$
\begin{gathered}
y_{N, t}=c_{N, t} \\
c_{N, t}=-\theta_{1}\left(p_{N, t}-p_{t}\right)+c_{t}=-\theta_{1} p_{N, t}+\theta_{1}\left[\left(1-\gamma_{1}\right) p_{T, t}+\gamma_{1} p_{N, t}\right]+c_{t}
\end{gathered}
$$


Replacing $p_{t}$ by $(2.20)$

$$
c_{N, t}=-\theta_{1} p_{N, t}+\theta_{1}\left[\left(1-\gamma_{2}\right) p_{H, t}+\gamma_{2} p_{F, t}\right]-\theta_{1} \gamma_{1}\left[\left(1-\gamma_{2}\right) p_{H, t}+\gamma_{2} p_{F, t}\right]+\theta_{1} \gamma_{1} p_{N, t}+c_{t}
$$

Employing the definition of the terms of trade (in log-linearized form) yields

$$
y_{N, t}=c_{N, t}=-\theta_{1} \gamma_{2}\left(1-\gamma_{1}\right) v_{t}+\theta_{1}\left(\gamma_{1}-1\right)\left(p_{N, t}-p_{H, t}\right)+c_{t}
$$

The equilibrium in the goods market for the whole economy will be given by the weighted average of the market clearing condition for the different sectors as

$$
y_{t}=\left(1-\gamma_{1}\right) y_{H, t}+\gamma_{1} y_{N, t}
$$

The price differential between domestically produced tradable and non-tradable goods appears to be one of the most important variables in determining the equilibrium of the model. This price differential can be referred to as the terms of trade of the non-tradable goods sector relative to the tradable, as pointed in previous sections. We introduce a definition and develop the evolution of this price differential as follows:

$$
\mu_{t}=p_{N, t}-p_{H, t}
$$

Subtracting one period lag of (2.71) from (2.71), we obtain the following equation of the evolution of the price differential between tradable and non-tradable sector.

$$
\mu_{t}=\mu_{t-1}+\pi_{N, t}-\pi_{H, t}
$$

\subsection{Monetary policy rules}

Economies in SSA employ different monetary policy rules, which implies the difficulty of talking about a single monetary policy rule applying to all countries in the region. Furthermore, most of the countries in the region use policy regimes that are quite different from the simple or modified Taylor rule common in the DSGE literature (for details, see Adam et al 2009, 2008). However, as we indicated from the outset, our objective in this study is to examine whether introducing the foreign exchange constraint into the standard model contributes towards explaining the dynamics of macroeconomic variables. Hence, we defer the modification of monetary policy rules to subsequent work and in this study we use the simple Taylor type rule where the monetary authority is assumed to act to stabilize inflation, output and exchange rate. Hence, the monetary authority adjusts the nominal interest rate in response to deviations of inflation, output and exchange rate from their steady-state values:

$$
r_{t}=\rho_{r} r_{t-1}+\left(1-\rho_{r}\right)\left(\phi_{\pi} \pi_{t}+\phi_{y} y_{t}+\phi_{e} \Delta e_{t}\right)+\epsilon_{r, t}
$$


where $\phi_{\pi}, \phi_{y}$, and $\phi_{e}$ are weights put by monetary authority, respectively, on inflation, GDP, and depreciation of the exchange rate. The lagged interest rate serves for interest rate smoothing while $\rho_{r}$ denotes the extent of persistence of interest rate. The monetary policy shock is captured by $\epsilon_{r, t}$ which is i.i.d normal error term with zero mean and standard deviation $\sigma_{\epsilon r}$.

\subsection{The External Sector}

The economies in SSA are small relative to the global economies and hence they cannot affect the foreign variables like income, inflation, interest rate, etc, that might significantly affect the performance of their macroeconomy. Therefore, the foreign economy can be modelled as exogenous. Following the literature in this area, we assume that the foreign variables follow first order autoregressive processes:

$$
\begin{aligned}
& y_{t}^{*}=\rho_{y^{*}} y_{t-1}^{*}+\epsilon_{y^{*}, t}, 0<\rho_{y^{*}}<1 \\
& \pi_{t}^{*}=\rho_{\pi^{*}} \pi_{t-1}^{*}+\epsilon_{\pi^{*}, t}, 0<\rho_{\pi^{*}}<1 \\
& r_{t}^{*}=\rho_{R^{*}} r_{t-1}^{*}+\epsilon_{r^{*}, t}, 0<\rho_{r^{*}}<1
\end{aligned}
$$

where $\pi_{t}^{*}$, and $r_{t}^{*}$ represent the foreign economy variables inflation and interest rate, respectively. $y_{t}^{*}$ is the log-deviation of foreign GDP from its steady-state and $\epsilon_{i, t}$ is an i.i.d normal error term with zero mean and standard deviation of $\sigma_{i}$, where $i$ stands for $y_{t}^{*}, \pi_{t}^{*}$ and $r_{t}^{*}$.

\section{Calibration and Simulation}

\subsection{Calibration of parameters}

It is important to know whether the modification we introduced is supported by stylized facts about the economies in the region in addition to the theoretical consistency. As discussed in DeJong and Dave (2007), calibration is the quickest way to assess the usefulness of successive extensions or modifications of a model. Accordingly, to simulate the model and then to compare the dynamics of some fundamental macroeconomic variables in response to various shocks with that of the standard model, parameters of the model are calibrated. The tradition in calibration exercises is either to borrow the parameters from the literature on the economies of similar structure, or to estimate them from actual data for a specific economy, or, as in many New Keynesian DSGE models, a mix of both. In this paper, we employed 
the first procedure and borrowed most of the parameters from the literature on the economies of the region. However, there is no literature available on some of the model parameters of this study, such as the parameters of price stickiness. For such parameters, unavoidably, the values are assigned based on subjective judgment using the values of the parameters for developed countries as a reference. The DYNARE $^{9}$ toolbox is used to solve the model numerically and generate the impulse response functions to different domestic and external shocks. The complete list of the parameters of the model and their values are in table 1 below.

Table 1: Model parameter values*

\begin{tabular}{lll}
\hline \hline$\alpha_{1}=0.49$ & $\gamma_{2}=0.3$ & $\phi_{e}=0.80$ \\
$\alpha_{2}=0.22$ & $\varsigma_{F}=0.20$ & $\rho_{Z H}=0.74$ \\
$\beta=0.99$ & $\varsigma_{H}=0.75$ & $\rho_{Z N}=0.90$ \\
$\sigma=2.96$ & $\varsigma_{N}=0.80$ & $\rho_{y^{*}}=0.75$ \\
$\varphi=3$ & $\epsilon_{F}=0.40$ & $\rho_{\pi^{*}}=0.60$ \\
$\eta=0.24$ & $\epsilon_{H}=0.45$ & $\rho_{r^{*}}=0.66$ \\
$\theta_{1}=12$ & $\epsilon_{N}=0.10$ & \\
$\theta_{2}=12$ & $\rho_{r}=0.80$ & \\
$h=0.25$ & $\phi_{y}=0.50$ & \\
$\gamma_{1}=0.731$ & $\phi_{\pi}=0.30$ & \\
\hline \hline
\end{tabular}

*The sources of the values for the parameters are given in the Appendix (section 5.3).

\subsection{Impulse Response Functions}

Since we are interested in comparing the behavior of the model with the exchange rate constraint (the modified model) with that of the standard model (without the constraint) in response to various shocks, we examine the impulse-response functions of selected variables. To this effect, we consider seven shocks; four of which are external and three domestic shocks. The external shocks considered are the foreign income shock, foreign monetary policy shock, foreign inflation shock and the terms of trade shock. On the other hand, the domestic shocks include productivity shocks to both tradable and non-tradable goods sectors and the monetary policy shock. All shocks are temporary and the figures presented below show the percentage deviations of the variables from their steady states. We will discuss the first three external shocks and three domestic shocks and finally discuss the terms of

\footnotetext{
${ }^{9}$ DYNARE is a free MATLAB toolkit to solve, simulate and estimate DSGE and a wide variety of other models. It is downloadable at http://www.dynare.org/.
} 

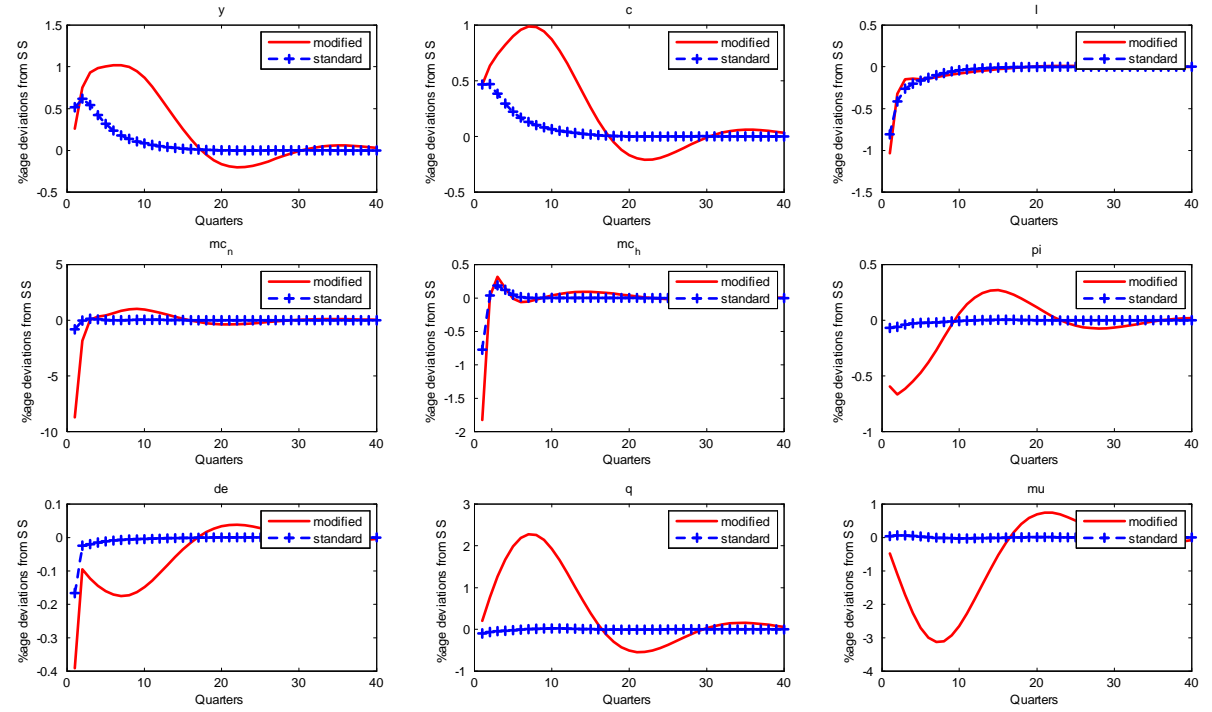

Figure 1: Impulse Responses to a foreign income shock

trade shock. The reason for this arrangement is that the impulse response functions of the terms of trade shock have some peculiar features compared to the impulse response functions of the other six structural shocks.

One clearly observable result is that the modified model generates more variations in most of the variables considered than the standard model. This is in line with the stylized facts about the behavior of macroeconomic variables of developing and low income countries. For instance, according to Stiglitz et al (2006: 57) one of the differences in macroeconomic behavior between developed and developing countries is that the latter are "less able to absorb shocks, and the structures of their economies are more likely to amplify shocks than dampen them" which is vividly observable in the impulse response functions below. This vulnerability of low income countries to shocks and their inability to absorb the shocks are discussed in many works (see, among others, Ndulu and O'Connell, 2008; Collier and Gunning, 1999; Kose and Reizman, 2001; Cashin, et al 2004).

Figure $1^{10}$ shows the impulse response to a foreign output shock. In both models output and consumption respond positively to the shock but the variation in both variables is higher in the modified model than in the standard model. This is so since in the standard model the foreign output

\footnotetext{
${ }^{10}$ Note: $\mathrm{y}=$ income, $\mathrm{c}=$ consumption, $\mathrm{l}=$ labour, $m c_{h}=$ marginal cost of tradable sector, $m c_{n}=$ marginal cost of non-tradable sector, $\mathrm{pi}=$ inflation, $\mathrm{de}=$ expected depreciation/appreciation, $\mathrm{q}=$ real exchange rate, $\mathrm{mu}=$ terms of trade of non-tradable sector relative to tradable sector
} 
affects domestic output and consumption through domestic export and international risk sharing, respectively. In the modified model the effect is magnified by the effect of foreign output on production of non-tradable goods. The initial impact of increasing foreign income decreases marginal costs in both sectors, and hence leads to deflationary pressure on the economy. On the other hand, the demand effect of the foreign output will increase the competitiveness of the domestic economy. However, there are two opposing outcomes of this demand effect. The export of the domestic economy increases and at the same time the cost of intermediate inputs increases, too. Both put upward pressure on domestic inflation which prompts the monetary authority to respond by raising interest rate which stabilizes output, consumption and inflation bringing the economy back to steady state.

Likewise, a foreign inflation shock has positive effects on output, consumption, and marginal costs in both sectors. The marginal cost in the tradable sector increases as increasing demand means increasing production and hence demand for more inputs. The marginal cost in the non-tradable sector increases for another reason. As in the case of a foreign output shock, a foreign inflation shock will increase the real exchange rate of the domestic economy (i.e., real depreciation) which increases the competitiveness of the domestic economy. This effect can be seen from increasing output and consumption due to increasing exports. However, there is another effect of this real exchange rate depreciation. That is, the cost of importing intermediate inputs will increase which leads to increasing marginal costs and hence domestic inflation. Again, both models show qualitatively the same effects but the magnitudes are more pronounced in the modified model.

The two models show close impulse responses for a foreign monetary policy shock. As can be seen from Figure 3, the two models diverge in the impulse responses of consumption and the evolution of non-tradable prices relative to the tradable counterparts (the terms of trade of non-tradable goods relative to tradable goods). In the case of the terms of trade of non-tradable goods relative to their tradable counterparts, the initial impact of a foreign monetary policy shock is opposite for the two models. Increasing the foreign policy interest rate (say due to tight monetary policy) causes the domestic currency to depreciate which increases the cost of the imported intermediate inputs. This results into increasing terms of trade of the non-tradable goods relative to tradable goods. On the other hand, since there is no effect of cost of intermediate inputs in the standard model the depreciation of domestic currency due to increasing foreign policy interest rate leads only to increasing domestic currency price of tradable goods. This explains why the terms of trade of non-tradable goods decreases in the standard model.

The impulse responses of some variables to a domestic productivity shock to the tradable goods 

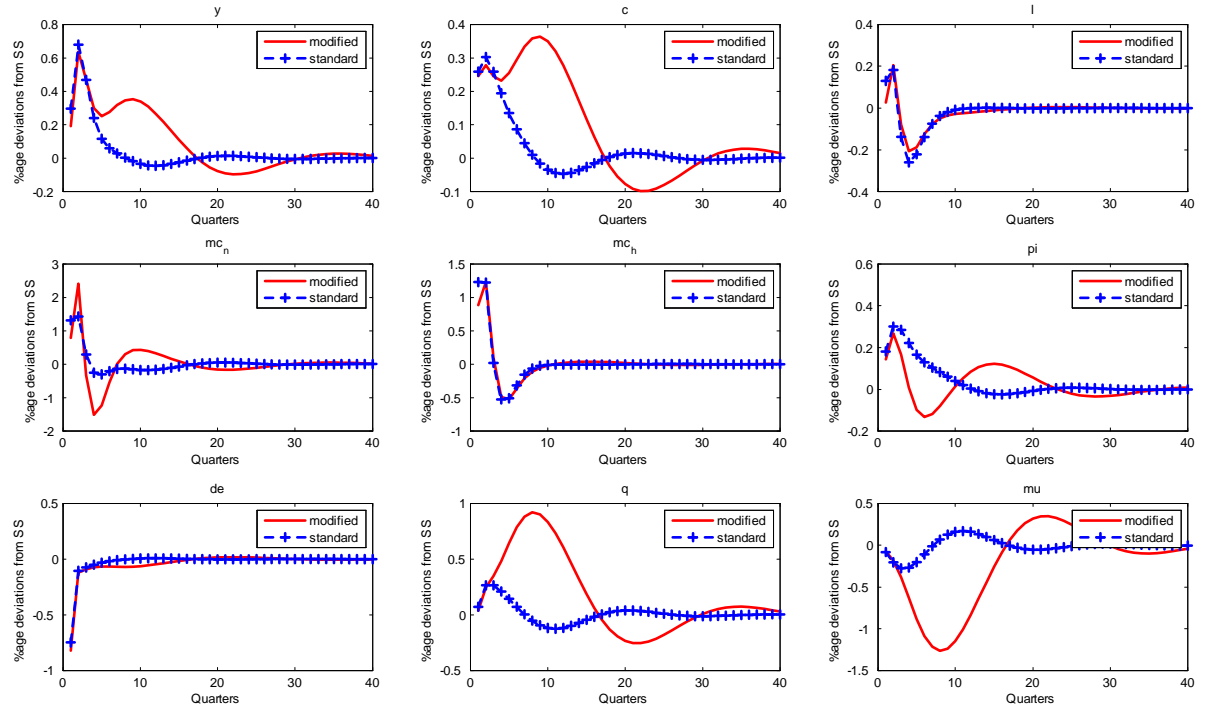

Figure 2: Impulse Responses to a foreign inflation shock
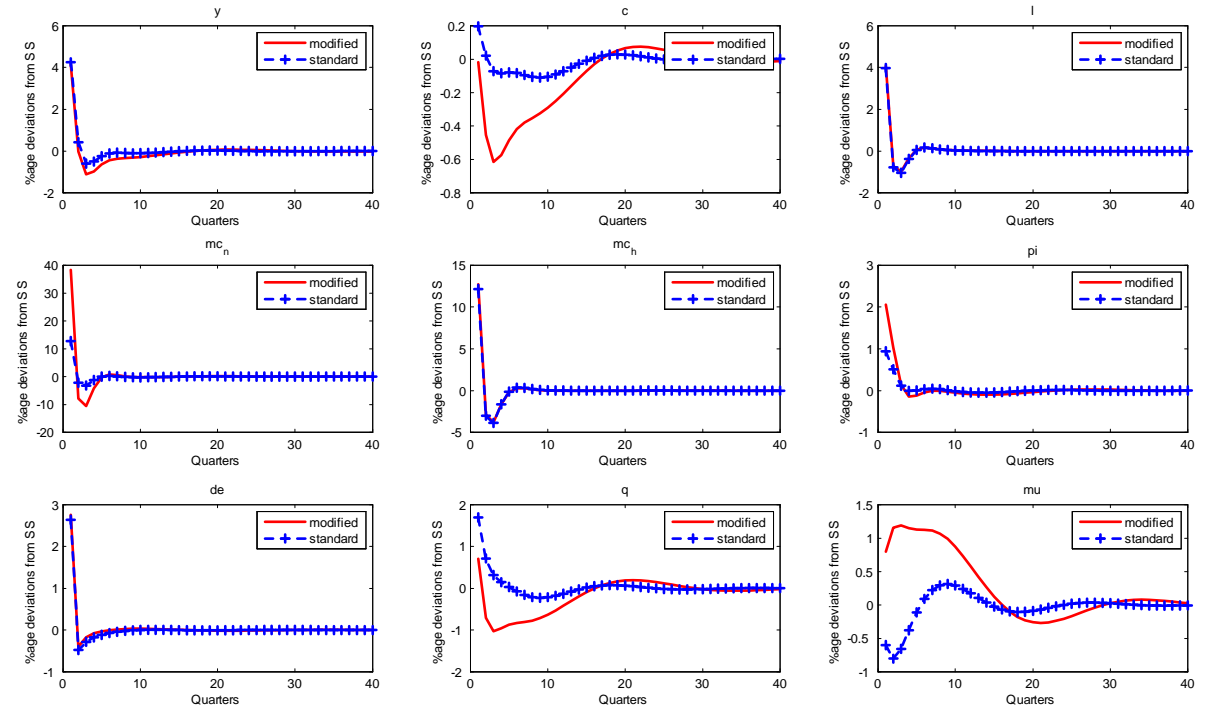

Figure 3: Impulse Responses to a foreign monetary policy shock 

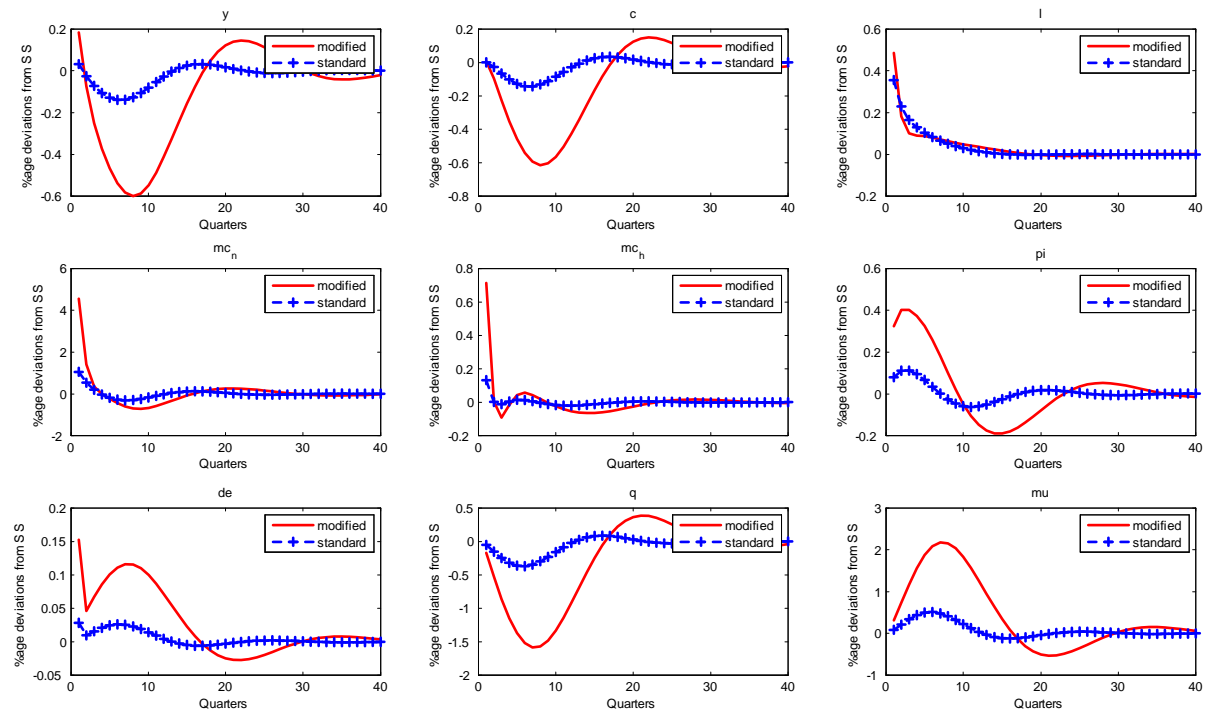

Figure 4: Impulse Response to a productivity shock (tradable goods)

sector of both models seem counter intuitive. As can be seen from Figure 4, as a result of productivity shock in the tradable goods sector, employment increases and consumption decreases. Output shows a tendency to increase at the initial impact of the shock and decreases thereafter. This can be explained as follows. First, the productivity in the tradable goods sector increases output, and demand for labour. The demand for labour increases the wage rate in both sectors (note that free mobility and equalization of wages are assumed). This increasing wage rate results into rising costs of production in both sectors and leads to decreasing output in the non-tradable sector. Given the small share of tradable goods in total output (assumed to be about 27 percent), the cost effect of increasing productivity in the tradable goods sector to the whole economy is greater than its contribution to the total output of the economy. Therefore, total output decreases. The decreasing consumption can be attributed first to the initial effect of productivity on substitution between consumption and labour and second to the decreasing output in the non-tradable sector. Both models indicate that the improved productivity in the tradable sector (which is a small sector) has distortionary effect on the economy as a whole.

The effect of a domestic productivity shock in the non-tradable sector shows the conventional impulse responses to a productivity shock. This is not surprising given that the non-tradable sector constitutes about 73 percent of the whole GDP and its production is mainly for domestic consumption. The direction of the effect of a productivity shock in the non-tradable sector is the same for both 

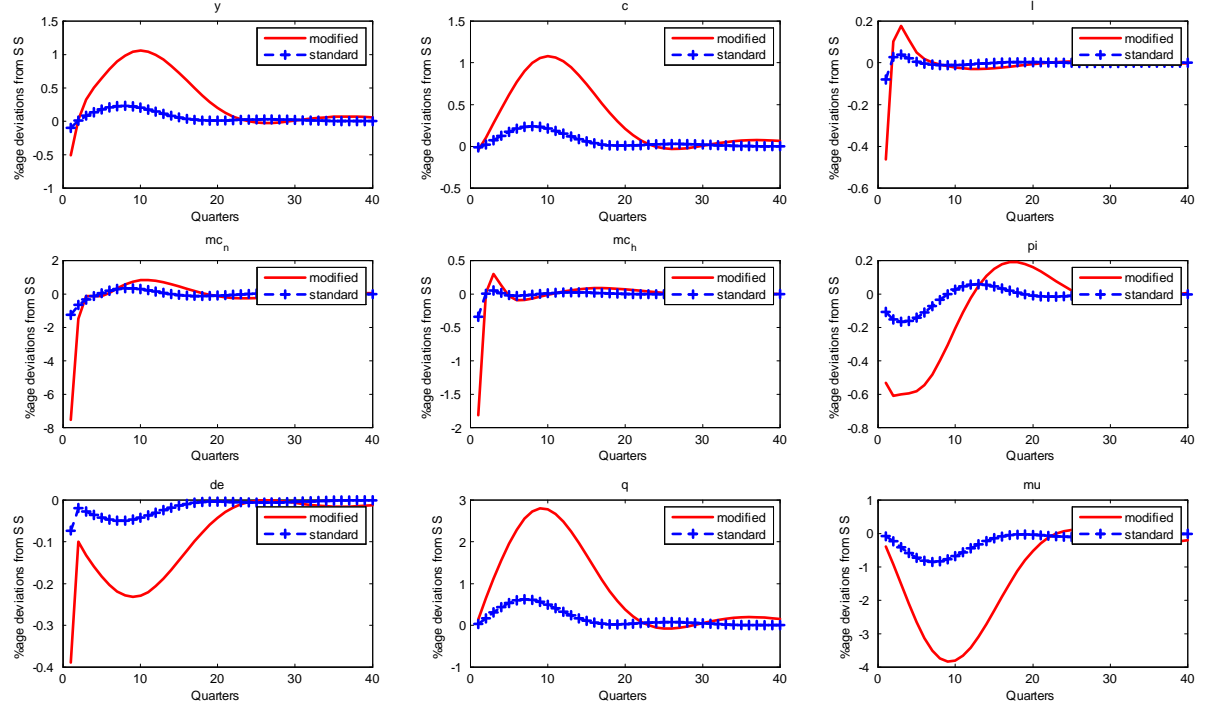

Figure 5: Impulse Responses to a productivity shock (non-tradable goods)

models but the magnitude is more pronounced for the modified model. The impulse responses show that output, consumption, and employment increase as a result of the shock. Furthermore, due to decreasing marginal costs in both sectors, there is a tendency for the domestic economy to experience deflationary pressure. However, the increasing domestic consumption means increasing demand for imports since total consumption is partly imported goods. This will put upward pressure on the real exchange rate which increases cost of production and overall inflation at which stage the monetary authority's intervention leads the economy to its steady state.

The two models yield the same qualitative result for most of the variables except that, as in the previous cases, the modified model has magnified variations for some of the variables. The two models have different impulse responses for the terms of trade of the non-tradable sector relative to the tradable sector. This difference results from the effect of the monetary policy shock on cost of production in the non-tradable sector. In the modified model, the increasing policy interest rate leads to the appreciation of domestic currency which reduces the cost on imported intermediate inputs in terms of domestic currency. The price of non-tradables relative to those of tradable goods will fall as indicated by the impulse responses of the modified model.

As demonstrated in Figure 6, the impulse responses to a domestic monetary policy shock differ in the duration of the effect of the shock and, therefore, the turning points. In all cases, not surprisingly, the modified model shows relatively higher variations. 

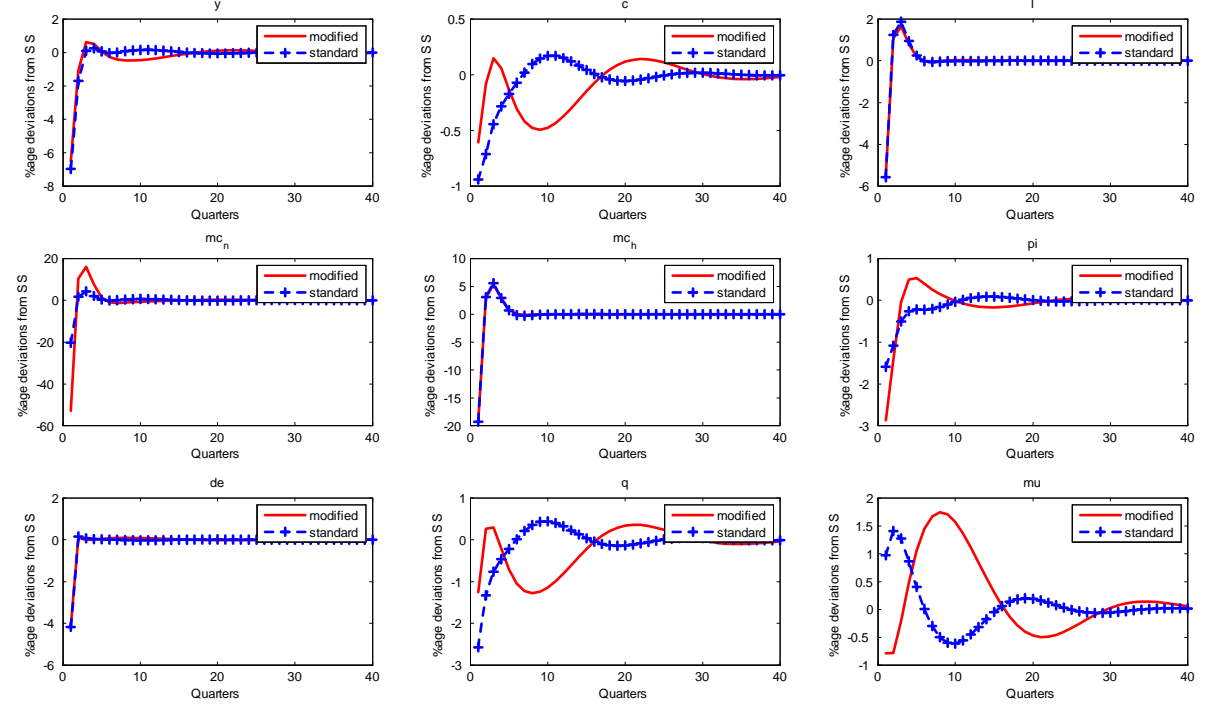

Figure 6: Impulse Responses to a domestic monetary policy shock

The last type of shock considered in this paper to compare the two models is a terms of trade shock, one of the most important external shocks to low income countries. The terms of trade is defined as a ratio of domestic currency price of home produced tradable goods to the domestic currency price of imported goods. Both prices are exogenous to the model economy since this is small open economy that is price taker for both its exports and imports. Figure 7 shows the impulse responses to a terms of trade shock. The improvement in terms of trade tends to increase output, consumption and employment at initial impact. However, at the same time, this improvement in terms of trade will lead to increasing cost of production in the tradable sector as demand for more output in the sector means demand for more inputs. On the other hand, the improvement in terms of trade leads domestic households to substitute consumption of tradable by non-tradable goods which puts upward pressure on the cost of production in the non-tradable sector and thereby price of non-tradable goods. Again as in the foreign monetary policy shock, the modified model implies increasing terms of trade of non-tradable goods relative to tradable goods as it captures the effect of increasing demand and increasing cost of importing intermediate inputs.

Closer examination of the impulse responses to terms of trade shock reveals some anomaly. That is, for some of the variables the impulse response functions do not converge to the steady state after the shock. This might be attributed to the way we defined the evolution of the terms of trade. As can be seen from (5.18 in the appendix), the equation of the evolution of terms of trade is not stationary. 

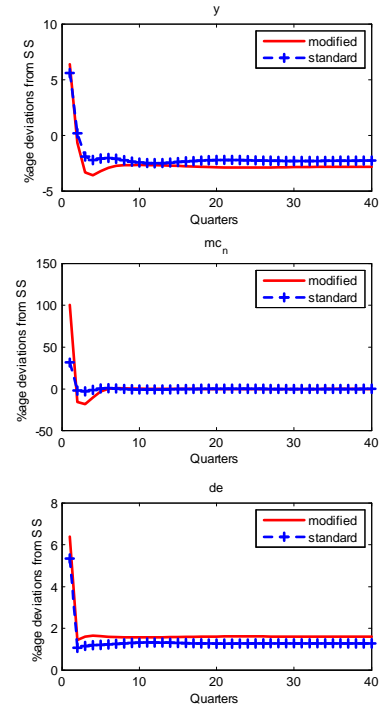
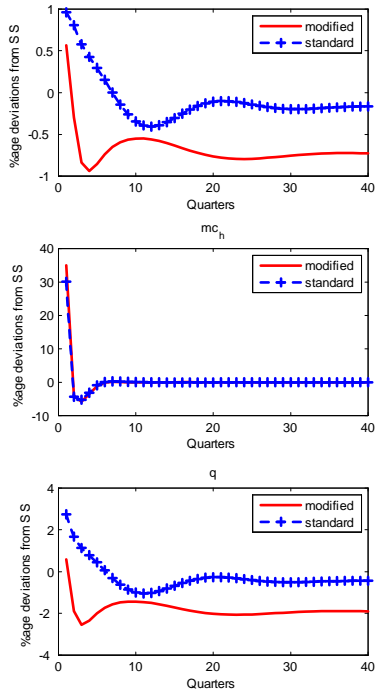
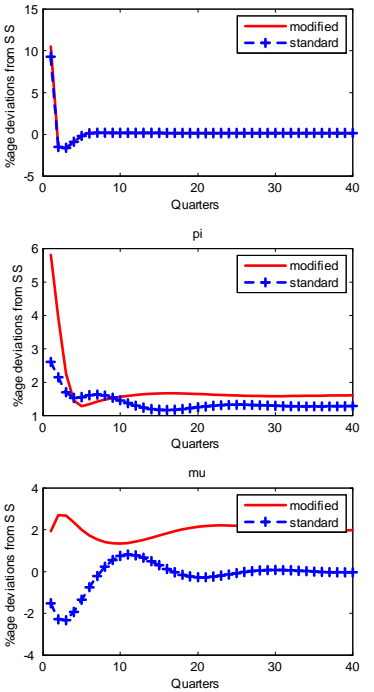

Figure 7: Impulse Responses to a terms of trade shock

Hence, unlike the other exogenous variables in the model, any shock to the terms of trade will be there permanently. As a result most of the variables (income, consumption, inflation, change in nominal exchange rate, real exchange rate, and the terms of trade of non-tradable sector relative to the tradable sector) do not converge to the steady state and hence the deviation from steady-state seems to stay permanently. One possible interpretation of this result is that the terms of trade shock will lead to a permanent change in the economy's structure and hence to a new steady-state. In this case, the impulse response functions do not measure the deviation of the variables from the initial steady-state, but the distance between the old and new steady-state. Though a more thorough investigation of this permanent effect of the terms of trade shock is interesting by its own, it does not have any effect on the objective of this paper - comparing the performance of the two models being hit by the same shock. This is so since this equation enters both models in the same way.

\subsection{Sensitivity analysis}

We made an informal check of the accuracy of the model by varying the value of some of the model parameters - which can be considered as sensitivity analysis. This attempt is constrained by the fact that there are only few empirical studies that are conducted on the economies of the region in a DSGE framework to see the range of parameters used (see Kose and Reizman, 2001; Peiris and Saxegaard, 2007; Dagher et al, 2010). Also, since the few studies that exist are meant to address quite different 
questions there are few parameters that they share in common with our paper which implies that there are few parameters to be borrowed. For the basic parameters of preferences, technology and monetary policy, we used the range of values assigned by these studies and we found that the impulse responses of most of the variables remain the same (qualitatively). However, the model seems to be very sensitive to the variation in the parameters of price setting. However, as discussed in Cooley (1997), judging the accuracy of a calibrated model via such a sensitivity analysis is questionable.

\section{Conclusion}

In this paper we formalized the claim that availability of foreign exchange is an important factor determining economic activity in developing and low-income countries. Low income countries rely heavily on imported capital and intermediate inputs. These imports, in turn, depend on the availability of foreign exchange at the disposal of the economy. Hence, the performance of the external sector of the economy in generating foreign exchange is critical to the performance of the rest of the macroeconomy of these countries. As a result, in the event of a global financial crisis, these countries are expected to be hard-hit. Hence, understanding the behavior of the macroeconomy of these countries in response to various domestic and global shocks requires modeling the foreign exchange constraint. To this effect, we introduced a foreign exchange constraint that imported input dependent firms face within the open economy New Keynesian DSGE model.

The main contribution of this study, as a first study to incorporate a foreign exchange constraint in a DSGE model, is enhancing our understanding of the response of macroeconomic variables of low income countries to various shocks. First, the impulse response functions of the model with a foreign exchange constraint (the modified model) and of the standard model show that the modified model generates more variability in most of the common macroeconomic variables considered when hit by the same domestic and external shocks. This result corresponds with the stylized facts about the behavior of macroeconomic variables of low income countries in an event of domestic and external shocks. Second, the model enables dealing with other global shocks that low income countries encounter (which are not addressed in this paper) if (2.51) is employed instead of its simplified version that we introduced.

Finally, it is important to note that some of the parameter values are not available from previous studies on the economies of the region, as discussed in the previous section. As a result, though the analysis based on the parameters above suffices to the objective of this paper, a more reliable evaluation 
of the performance of the models requires estimating the parameters from actual data. This is the objective of the final part of our research project where the model with additional modifications will be estimated.

\section{References}

[1] Adam, Christopher; Stephen O'Connell and Edward Buffie (2008) Aid volatility, monetary policy rules and the capital account in African economies. World Economy \& Finance Research Programme, Birkbeck, University of London. Working Paper Series WEF 0037.

[2] Adam, Christopher; Stephen O'Connell, Edward Buffie, and Catherine Pattillo(2009) Monetary Policy Rules for Managing Aid Surges in Africa. Review of Development Economics, Vol. 13, No. 3: 464-490.

[3] Agenor, P.R. and P.J. Montiel (2008) Development Macroeconomics, 3rd ed. Princeton University Press.

[4] Bigsten, Arne, Paul Collier, Stefan Dercon, Marcel Fafchamps, Bernard Gautheirs, Jan Wellem Gunning, Abena Oduro, Remco Oostendorp, Cathy Patillo, Mans Soderborn, Francis Teal, and Albert Zeufack (2003) Credit Constraints in Manufacturing Enterprises in Africa. Journal of African Economies, Vol. 12, No. 1:104-125.

[5] Bulir, Ales and Javier Hamann (2008) Volatility of Development Aid: From the Frying Pan into the Fire? World Development, Vol.36, No.10: 2048-2066.

[6] Bulir, Ales and Javier Hamann (2003) Aid Volatility: An Empirical Assessment. IMF Staff Papers, vol 50, No.1:64-89.

[7] Calvo, Guillermo A. (1983) Staggered prices in a utility-maximizing framework. Journal of Monetary Economics, Vol. 12, No. 3: 383-98.

[8] Cashin, Paul, C. John McDermott, and Catherine Pattillo (2004) Terms of trade shocks in Africa: are they short-lived or long-lived? Journal of Development Economics 73:727- 744.

[9] Collier, Paul and Jan Willem Gunning (1999) Explaining African Economic Performance. Journal of Economic Literature, Vol. 37, No. 1: 64-111. 
[10] Cooley, Thomas F. (1997) Calibrated models. Oxford Review of Economic Policy, Vol. 13, No. 3 : $55-69$.

[11] Dagher, Jihad, Jan Gottschalk, and Rafael Portillo (2010) Oil windfalls in Ghana: A DSGE Approach. IMF Working Paper WP/10/116.

[12] DeJong, David N. with Chetan Dave (2007) Structural Macroeconometrics. Princeton University Press.

[13] Eicher, Theo S., Stefan F. Schubert and Stephen J. Turnovsky (2008) Dynamic effects of terms of trade shocks: The impact on debt and growth. Journal of International Money and Finance, 27: 876-896.

[14] Fafchamps, Marcel (2004) Market Institutions in Sub-Saharan Africa: Theory and Evidence. The MIT Press.

[15] Gali, Jordi (2008) Monetary policy, Inflation, and the Business Cycle: An Introduction to the New Keynesian Framework. Princeton University press.

[16] Gali, Jordi and Tommaso Monacelli (2005) Monetary Policy and Exchange Rate Volatility in a Small Open Economy. Review of Economic Studies 72: 707-734.

[17] Holmberg, Karolina (2006) Derivation and Estimation of a New Keynesian Phillips Curve in a Small Open Economy. Sveriges Riksbank Working Paper Series, No. 197.

[18] Kose, M. Ayhan and Raymond Riezman (2001) Trade shocks and macroeconomic fluctuations in Africa. Journal of Development Economics, Vol. 65:55-80.

[19] Kose, M. Ayhan (2002) Explaining business cycles in small open economies 'How much do world prices matter?' Journal of International Economics, 56: 299-327.

[20] Lensink, Robert (1995) Foreign exchange constraints and developing countries. Economic Modelling, Vol. 12, No. 2:179-191.

[21] Liu, Phillip (2006) A small New Keynesian model of New Zealand. Discussion paper DP2006/03. Reserve Bank of New Zealand.

[22] McCallum, Bennet T. and Edward Nelson (1999) An Optimizing IS-LM Specification for Monetary Policy and Business Cycle Analysis. Journal of Money, Credit, and Banking, Vol. 31, No. 3: 296-316. 
[23] Matheson, Troy (2010) Assessing the fit of small open economy DSGEs. Journal of Macroeconomics 32 : 906 - 920.

[24] Mkrtchyan, Ashot; Era Dabla-Norris, and Ara Stepanyan (2009) A New Keynesian Model of the Armenian Economy. IMF Working Paper WP/09/66.

[25] Monacelli, Tommaso (2005) Monetary policy in a low pass-through environment, Journal of Money, Credit and Banking 37: 1047-1066.

[26] Moran, Cristian (1989) Import under a Foreign Exchange Constraint. The World Bank Economic Review, Vol. 3, No. 2:279-295.

[27] Ndulu , Benno J. and Stephen A. O'Connell (2008) Policy plus: African growth performance, 1960-2000; in Ndulu, Benno J., Stephen A. O'Connell, Robert H. Bates , Paul Collier and Chukwuma C. Soludo (eds.) The Political Economy of Economic Growth in Africa, 1960-2000 Volume 1. Cambridge University Press.

[28] Peiris, Shanaka J. and Magnus Saxegaard (2007) An Estimated DSGE Model for Monetary Policy Analysis in Low-Income Countries. IMF Working Paper WP/07/282.

[29] Polterovich, Victor and Vladimir Popov (2003) Accumulation of Foreign Exchange Reserves and Long Term Growth. http://www.nes.ru/english/about/10th-Anniversary/papers-pdf/PopovPolterovich.pdf.

[30] Porter, R. and S. Ranney (1982) An Eclectic Model of Recent LDC Macroeconomic Policy Analysis. World Development, Vol. 10 No. 9 pp. 751-765.

[31] Santacreu, Ana Maria (2005) Reaction functions in a small open economy: what role of non-traded inflation? Discussion paper DP2005/04. Reserve Bank of New Zealand.

[32] Schmitt-Grohe, Stephanie and Martin Uribe (2003) Closing small open economy models. Journal of International Economics 61:163-185.

[33] Snowdon, Brian and Howard R. Vane (2005) Modern Macroeconomics: Its origins, development and current state. Edward Elgar Publishing Inc.

[34] Stiglitz, Joseph E.; Jose Antonio Ocampo, Shari Spiegel, Ricardo Ffrench-Davis, and Deepak Nayyar (2006) Stability with Growth: Macroeconomics, Liberalization, and Development.Oxford University Press. 
[35] Walsh, Carl (2010) Monetary Theory and Policy, 3rd edition. The MIT press.

[36] Wyplosz, Charles (2007) The Foreign Exchange Reserves Buildup: Business as Usual? Paper presented on Workshop on Debt, Finance and Emerging Issues in Financial Integration, 6-7 March 2007, Commonwealth Secretariat, Marlborough House, London. 


\section{Appendix}

\subsection{Log-linearized Model Equations}

Consumption equation can be derived by combining the Euler equation with the international risk sharing condition, the later moved one period forward.

$$
c_{t}=\frac{h}{1+h} c_{t-1}+\frac{1}{1+h} E_{t}\left[h c_{t}+y_{t+1}^{*}-h y_{t}^{*}+\frac{(1-h)}{\sigma} q_{t+1}\right]-\frac{1-h}{\sigma(1+h)}\left(r_{t}-E_{t} \pi_{t+1}\right)
$$

Goods market clearing condition

$$
\begin{gathered}
y_{H, t}=c_{H, t}+c_{H, t}^{*} \\
c_{H, t}=-\gamma_{2}\left(\theta_{2}-\theta_{1} \gamma_{1}\right) v_{t}+\theta_{1} \gamma_{1}\left(p_{N, t}-p_{H, t}\right)+c_{t} \\
c_{H, t}^{*}=-\theta_{2} \gamma_{2}\left(1-\gamma_{1}\right) v_{t}+\theta_{2} \gamma_{1}\left(p_{N, t}-p_{H, t}\right)+c_{t}^{*}+\theta_{2} q_{t} \\
y_{H, t}=-\gamma_{2}\left(\theta_{2}-\theta_{1} \gamma_{1}\right) v_{t}+\theta_{1} \gamma_{1}\left(p_{N, t}-p_{H, t}\right)+c_{t}-\theta_{2} \gamma_{2}\left(1-\gamma_{1}\right) v_{t}+\theta_{2} \gamma_{1}\left(p_{N, t}-p_{H, t}\right)+c_{t}^{*}+\theta_{2} q_{t} \\
y_{N, t}=c_{N, t}=-\theta_{1} \gamma_{2}\left(1-\gamma_{1}\right) v_{t}+\theta_{1}\left(\gamma_{1}-1\right)\left(p_{N, t}-p_{H, t}\right)+c_{t} \\
y_{t}=\left(1-\gamma_{1}\right) y_{H, t}+\gamma_{1} y_{N, t}
\end{gathered}
$$

Productivity in domestic tradable sector

$$
z_{H, t}=\rho_{H} z_{H, t-1}+\epsilon_{H, t}
$$

Productivity in non-tradable sector

$$
z_{N, t}=\rho_{N} z_{N, t-1}+\epsilon_{N, t}
$$

The Uncovered interest Parity Condition

$$
E_{t} e_{t+1}-e_{t}=r-r^{*}+\epsilon_{u i p, t}
$$

Marginal cost in the tradable sector

$$
m c_{H, t}=\varphi l_{t}+\frac{\sigma}{1-h}\left(c_{t}-h c_{t-1}\right)-z_{H, t}-\gamma_{2}\left(1-\gamma_{1}\right) v_{t}+\gamma_{1}\left(p_{N, t}-p_{H, t}\right)
$$


Marginal cost non-tradable sector (standard)

$$
m c_{N, t}=\varphi l_{t}+\frac{\sigma}{1-h}\left(c_{t}-h c_{t-1}\right)-z_{N, t}-\gamma_{2}\left(1-\gamma_{1}\right) v_{t}+\left(\gamma_{1}-1\right)\left(p_{N, t}-p_{H, t}\right)
$$

Marginal cost in non-tradable sector (modified model)

$$
\begin{aligned}
m c_{N, t} & =\frac{1}{\alpha_{1}+\alpha_{2}}\left[y_{N, t}-z_{N, t}-\alpha_{2} m_{t}\right. \\
& +\alpha_{1}\left(\varphi l_{t}+\frac{\sigma}{1-h}\left(c_{t}-h c_{t-1}\right)-y_{N, t}-\gamma_{2}\left(1-\gamma_{1}\right) v_{t}+\left(\gamma_{1}-1\right)\left(p_{N, t}-p_{H, t}\right)\right) \\
& \left.+\alpha_{2}\left(m_{t}-v_{t}-y_{N, t}-\left(p_{N, t}-p_{H, t}\right)\right)\right]
\end{aligned}
$$

Imported intermediate input

$$
\left.m_{t}=\psi-\theta_{2} \gamma_{2}\left(1-\gamma_{1}\right)\right) v_{t}+\theta_{2} \gamma_{1}\left(p_{N, t}-p_{H, t}\right)+y_{t}^{*}+\theta_{2} q_{t}
$$

Domestically produced tradable goods inflation

$$
\pi_{H, t}=\kappa_{b, H} \pi_{T, t-1}+\kappa_{F, H} E_{t} \pi_{H, t+1}+\lambda_{H} m c_{H, t}
$$

Nontradable goods inflation

$$
\pi_{N, t}=\kappa_{b, N} \pi_{N, t-1}+\kappa_{F, N} E_{t} \pi_{N, t+1}+\lambda_{N} m c_{N, t}
$$

Imported inflation

$$
\pi_{F, t}=\kappa_{b, F} \pi_{F, t-1}+\kappa_{f, F} E_{t} \pi_{F, t+1}+\lambda_{F} \psi_{F, t}
$$

Tradable goods inflation

$$
\pi_{T, t}=\left(1-\gamma_{2}\right) \pi_{H, t}+\gamma_{2} \pi_{F, t}
$$

Overall CPI inflation

$$
\pi_{t}=\left(1-\gamma_{1}\right) \pi_{T, t}+\gamma_{1} \pi_{N, t}
$$

The evolution of law of one price gap

$$
\psi_{t}-\psi_{t-1}=e_{t}-e_{t-1}+\pi_{t}^{*}-\pi_{F, t}
$$

The evolution of the terms of trade

$$
v_{t}=v_{t-1}+\pi_{F, t}-\pi_{H, t}+\epsilon_{t o t, t}
$$


The relationship between real exchange rate and terms of trade

$$
q_{t}=\psi_{t}-\left(1-\gamma_{2}\left(1-\gamma_{1}\right)\right) v_{t}-\gamma_{1}\left(p_{N, t}-p_{H, t}\right)
$$

The evolution of price differential between the tradable and non-tradable sectors of the domestic economy

$$
\begin{aligned}
& \mu_{t}=p_{N, t}-p_{H, t} \\
& \mu_{t}=\mu_{t-1}+\pi_{N, t}-\pi_{H, t}
\end{aligned}
$$

Monetary policy rule

$$
r_{t}=\rho_{r} r_{t-1}+\left(1-\rho_{r}\right)\left(\phi_{\pi} \pi_{t}+\phi_{y} y_{t}+\phi_{e} \Delta e_{t}\right)+\epsilon_{r, t}
$$

The rest of the world

$$
\begin{aligned}
& y_{t}^{*}=\rho_{y^{*}} y_{t-1}^{*}+\epsilon_{y^{*}, t} \\
& \pi_{t}^{*}=\rho_{\pi^{*}} \pi_{t-1}^{*}+\epsilon_{\pi^{*}, t} \\
& r_{t}^{*}=\rho_{r^{*}} r_{t-1}^{*}+\epsilon_{r^{*}, t}
\end{aligned}
$$




\subsection{Definitions of symbols and Variables of the model}

\subsubsection{Definitions of symbols}

\begin{tabular}{|l|l|}
\hline \multicolumn{2}{|l|}{ Households } \\
\hline \hline$\beta$ & Agents' discount factor \\
\hline$\sigma$ & Elasticity of intertemporal substitution in consumption \\
\hline$\varphi$ & Elasticity of substitution between labour and leisure \\
\hline$\eta$ & Marginal disutility from working/utility cost of working \\
\hline$\theta_{1}$ & Elasticity of substitution between tradable and non-tradable goods in consumption \\
\hline$\theta_{2}$ & Elasticity of substitution between domestically produced tradable and imported goods \\
\hline$\gamma_{1}$ & The proportion of non-tradable in consumption \\
\hline$\gamma_{2}$ & The share of imports in total consumption of tradable goods production \\
\hline$\zeta$ & Elasticity of substitution between the varieties of tradable and non-tradable goods \\
\hline$\chi$ & A constant capturing relative initial asset position of domestic and foreign households \\
\hline \hline
\end{tabular}

Firms

\begin{tabular}{|l|l|}
\hline \hline$\alpha_{1}$ & Share of labour in the production of of non-tradable goods \\
\hline$\alpha_{2}$ & Share of intermediate inputs in production of non-tradable goods \\
\hline$\rho_{H}$ & Persistence of productivity shock in tradable sector \\
\hline$\rho_{N}$ & Persistence of productivity shock in non-tradable sector \\
\hline$\epsilon_{i}$ & Fraction of firms in sector i that cannot adjust/reset their prices \\
\hline$\varsigma_{i}$ & Fraction of firms in sector i that reset their prices using rule of thumb (backward-looking) \\
\hline$\vartheta$ & Fraction of foreign exchange inflow that the central bank offers for sale \\
\hline \hline
\end{tabular}

Monetary policy

\begin{tabular}{|c|l|}
\hline \hline$\rho_{r}$ & Persistence of interest rate \\
\hline$\phi_{\pi}$ & Inflation stabilization \\
\hline$\phi_{y}$ & Output stabilization \\
\hline$\phi_{e}$ & Exchange rate stabilization \\
\hline \hline
\end{tabular}




\subsubsection{Variables and their definitions}

\begin{tabular}{|c|c|}
\hline \multicolumn{2}{|c|}{ Endogenous variables } \\
\hline Variable & Definition \\
\hline$B$ & Domestic bond holdings \\
\hline$C, C_{F}, C_{H}, C_{N}$ & Private consumption \\
\hline$D$ & Dividends \\
\hline$\varepsilon$ & Nominal exchange rate \\
\hline$F$ & Holdings of domestic bond by foreigners \\
\hline$L=L_{H}+L_{N}$ & Labour employed in tradable and non-tradable sectors \\
\hline$M$ & Imported intermediate inputs \\
\hline$P$ & Overall price level \\
\hline$P_{F}$ & Domestic currency price of imported goods \\
\hline$P_{H}$ & Price of domestically produced tradable goods \\
\hline$P_{N}$ & Price of non-tradable goods \\
\hline$P_{T}$ & Price of tradable goods \\
\hline$Q$ & Real exchange rate \\
\hline$r$ & Nominal interest rate (the policy interest rate) \\
\hline$V$ & Terms of trade \\
\hline$W$ & Wage rate \\
\hline$X$ & Exports \\
\hline$Y_{H}$ & Output level of domestically produced tradable goods \\
\hline$Y_{N}$ & Output level of non-tradable goods \\
\hline$\pi_{F}$ & Inflation of prices of imported goods \\
\hline$\pi_{H}$ & Domestically produced tradable goods inflation \\
\hline$\pi_{N}$ & Non-tradable goods inflation \\
\hline$\pi_{T}$ & Tradable goods inflation \\
\hline$\pi$ & Overall inflation \\
\hline$\Omega$ & Stock of foreign exchange available to import intermediate inputs \\
\hline$\Psi$ & The law of one price gap \\
\hline
\end{tabular}




\begin{tabular}{|l|l|}
\hline \hline \multicolumn{2}{|l|}{ Exogenous variables } \\
\hline \hline Variable & Definition \\
\hline$Z_{H}$ & Total factor productivity in the non - tradable sector \\
\hline$Z_{N}$ & Total factor productivity in the tradable sector \\
\hline$Y^{*}$ & Output level of the rest of the world \\
\hline$R^{*}$ & Foreign interest rate \\
\hline$\pi^{*}$ & Foreign inflation rate \\
\hline$P_{x}$ & Price of exports \\
\hline
\end{tabular}

\subsection{Parameters and their values}

\subsubsection{Households}

\begin{tabular}{|l|l|l|}
\hline \hline Parameter & Value & Source \\
\hline$\beta$ & 0.99 & Dagher et al (2010) \\
\hline$\sigma$ & 2.96 & Kose and Reizman (2001) \\
\hline$\varphi$ & 3 & Dagher et al (2010) \\
\hline$\eta$ & 0.24 & $"$ \\
\hline$\zeta$ & 12 & $"$ \\
\hline$\theta_{1}$ & 12 & $"$ \\
\hline$\theta_{2}$ & 12 & $"$ \\
\hline$h$ & 0.25 & Peiris and Saxegaard (2007) \\
\hline$\gamma_{1}$ & 0.731 & $"$ \\
\hline$\gamma_{2}$ & 0.3 & Subjective judgment \\
\hline
\end{tabular}




\subsubsection{Firms}

\begin{tabular}{|l|l|l|}
\hline \hline Parameter & Value & source \\
\hline$\alpha_{1}$ & 0.49 & Kose and Reizman (2001) \\
\hline$\alpha_{2}$ & 0.22 & " \\
\hline$\varsigma_{F}$ & 0.20 & Subjective judgment \\
\hline$\varsigma_{H}$ & 0.75 & " \\
\hline$\varsigma_{N}$ & 0.80 & $"$ \\
\hline$\epsilon_{F}$ & 0.40 & $"$ \\
\hline$\epsilon_{H}$ & 0.45 & $"$ \\
\hline$\epsilon_{N}$ & 0.10 & $"$ \\
\hline \hline
\end{tabular}

\subsubsection{Monetary Policy Rules}

\begin{tabular}{|l|l|l|}
\hline \hline Parameter & Value & source \\
\hline$\varrho_{r}$ & 0.80 & Peiris and Saxegaard (2007) \\
\hline$\phi_{\pi}$ & 0.31 & $"$ \\
\hline$\phi_{y}$ & 0.50 & $"$ \\
\hline$\phi_{e}$ & 0.80 & $"$ \\
\hline \hline
\end{tabular}

\subsubsection{External sector}

\begin{tabular}{|l|l|l|}
\hline \hline Parameter & value & source \\
\hline$\rho_{r^{*}}$ & 0.66 & Peiris and Saxegaard $(2007)$ \\
\hline$\rho_{y^{*}}$ & 0.75 & $"$ \\
\hline$\rho_{\pi^{*}}$ & 0.60 & $"$ \\
\hline \hline
\end{tabular}




\subsection{Shocks}

\begin{tabular}{|l|l|}
\hline \hline$\epsilon_{Z H}$ & Productivity shoch (tradable sector) \\
\hline$\epsilon_{Z N}$ & Productivity shock (non-tradable sector) \\
\hline$\epsilon_{r}$ & Monetary policy shock \\
\hline$\epsilon_{t o t}$ & Terms of trade shock \\
\hline$\epsilon_{r^{*}}$ & Foreign monetary policy shock \\
\hline$\epsilon_{y^{*}}$ & Foreign income shock \\
\hline$\epsilon_{\pi^{*}}$ & Foreign inflation shock \\
\hline \hline
\end{tabular}

